\title{
DIAGENETIC IMPLICATIONS OF STYLOLITIZATION IN PELAGIC CARBONATES, CANTERBURY BASIN, OFFSHORE NEW ZEALAND
}

\author{
VEERLE VANDEGINSTE AND CÉDRIC M. JOHN \\ Department of Earth Science and Engineering, Imperial College London, SW7 2BP, London, U.K. \\ e-mail:v.vandeginste@imperial.ac.uk
}

\begin{abstract}
Stylolites are irregular discontinuity surfaces that are thought to result from localized stress-induced dissolution during burial or tectonic compression. The genesis of stylolites and the controls on stylolitization are still debated, and the interplay between stylolitization, generation of carbonate-rich fluids, diagenetic fluid flow within fractures and matrix, cementation, and porosity modifications is complex. All of these processes have important diagenetic effects potentially altering the intrinsic properties of the host rock, with implications for hydrocarbon exploration and water resources in aquifers. We investigate the process of stylolitization by a macroscopic, petrographic, and geochemical study of pressure-solution features in Eocene to early Oligocene limestones in cores from the Integrated Ocean Drilling Program (IODP) Hole 317-U1352C (Canterbury Basin). The results indicate correlations among stylolite amplitude, stylolite density, and siliciclastic content of the host rock. These relationships are interpreted to suggest that siliciclastic content in carbonate rocks increases heterogeneity, which in turn impacts stylolite nucleation. Moreover, the geochemical data support that clay along the stylolite is not authigenic, but a relict from impurities in the limestone host rock. The statistical approach of stylolite spacing used in this study, which is different than previous studies, reinforces the model of random occurrence of stylolites in (carbonate) lithologic units.

This study shows that local stresses in tectonically passive areas may allow the formation of rare oblique stylolites with peaks perpendicular to the stylolite plane. Estimation of the amount of limestone dissolved during stylolitization (minimum 7\% to $12 \%$ of the depositional limestone) and the volume of sparite in the host rock (up to $1.6 \%$ of the compacted limestone) suggests that the pressure-solution fluids cemented the micropores, reducing porosity to about $10 \%$ (from a common porosity of about $40 \%$ in mechanically compacted chalk). This study thus highlights the importance of microporosity as a sink for burial cements, an observation difficult to make in thin-section. Analysis of stylolite infills at Site U1352 shows no evidence that the stylolites acted as conduits for diagenetic fluids, unless if the fluid was host-rock buffered and thus its chemistry indistinguishable from that of the host rock.

The link between siliciclastic content in carbonate rocks and the spacing and amplitude of stylolites improves understanding of burial compaction processes. Predicting the morphology and spacing of stylolites in the subsurface can be used to identify baffles to cross-stylolite fluid flow or cementation (of microporosity) influencing heterogeneity of petrophysical properties in (subsurface reservoir) host rocks.
\end{abstract}

\section{INTRODUCTION}

Stylolites are irregular planes of discontinuity and are very common in carbonate rocks. They result from physicochemical processes induced by burial compaction or tectonic compression. Stylolites are one of the three pressure-solution features, along with solution seams and fitted fabrics (Buxton and Sibley 1981). The classification of stylolites used in most studies is based on visual descriptions of the macroscopic features, i.e., geometry and the relation to the bedding plane (Park and Schot 1968). More recently, stylolite roughness has been described using a more quantitative approach based on fractal concepts (Drummond and Sexton 1998; Karcz and Scholz 2003).

Whereas researchers agree on what stylolites are, their genesis is still a debated topic. The majority of the scientific community agrees that stylolites are caused by localized stress-induced dissolution of material along a fluid-filled interface (e.g., Dunnington 1954), but stylolites have been proposed to form: (1) along pre-existing anisotropies (Bathurst 1987), (2) as anticracks (Fletcher and Pollard 1981), or (3) by stressinduced self organization (Merino 1992). Factors that control stylolite morphology, geometry, and microstructures include compressive or tectonic stress, rock fabric, mineralogy and textural instabilities (e.g., Tada and Siever 1989; Sinha-Roy 2002). Recent research on stylolite formation has focused on modeling stylolite morphology and roughness (Koehn et al. 2007; Ebner et al. 2009a, 2009b, 2010).

Despite these efforts, a complete understanding of the controls on the initiation of stylolite formation remains elusive. For instance, whether clay minerals promote or inhibit stylolite formation, and how grain size and grain fabric or lithology (e.g., mudstone versus grainstone) impact on burial depth of stylolite initiation and stylolite morphology is still unclear. In addition, the interplay of stylolitization with fractures, porosity, cementation, and fluid flow is complex and poorly constrained. Nevertheless, stylolites are closely related to local mass 
transfer of dissolved material, compaction, and porosity reduction, which are important diagenetic processes affecting intrinsic properties of the host rocks (e.g., Tada and Siever 1989). The mass transfer during stylolitization consists of diffusion between particles or advection through microcracks or tension gashes. As a result, subsequent cementation can be localized in pores, or in the cracks and fractures (Raynaud and Carrio-Schaffhauser 1992). Stylolites are important in reservoirs because they cause highly directional, restricted zones of reduced porosity and permeability, and their impact on reservoirs is similar to that of tectonic gouge-filled fractures (Nelson 1981). Thus, the stylolites commonly are barriers to cross-stylolite fluid flow, but they can also represent open stylolite-parallel fluid pathways that develop when fluids in the surrounding rocks are overpressured (Braithwaite 1989).

This paper explores the origin and dynamics of stylolite formation from a diagenetic perspective, mainly based on petrography and geochemistry of limestone samples from the bottom $\sim 70 \mathrm{~m}$ cores of the Integrated Ocean Drilling Program (IODP) Hole 317-U1352C in the Canterbury Basin (New Zealand). The Canterbury Basin was host to rapid sedimentation during the Cenozoic, and abundant stylolites occur in the Amuri Limestone section recovered during IODP 317 (Fulthorpe et al. 2011); this setting makes it an ideal location to examine pressure solution associated with fracturing and cementation processes. Specific goals of this paper are: i) to assess the impact of lithology on stylolite morphology, ii) to gain insight into diagenetic fluid mobility during and after pressure solution, and iii) to reconstruct the timing and burial depth of stylolitization. The results of this study, which uses a different statistical approach to stylolite spacing than previously published by looking at a large, representative dataset ( $>800$ stylolites) within a lithologic unit, reinforces the model of random distribution of stylolites in lithologic units. The relation between quartz content and stylolite amplitude has been quantified and can be estimated by a power curve. Moreover, the mass balance documented here between stylolitizationrelated dissolution and cementation of calcite shows the importance of microporosity as a sink for stylolite-induced cements.

\section{GEOLOGICAL SETTING}

The Canterbury Basin lies on the landward rim of the New Zealand Plateau, a rifted continental fragment that includes the Campbell Plateau, the Chatham Rise, and the Bounty Trough (Fig. 1). The offshore Canterbury Basin lies close to a major plate boundary, i.e., the dextral strike-slip Alpine Fault (Fig. 1), which has led to a displacement of $500 \mathrm{~km}$ since the earliest Miocene (about $23 \mathrm{Ma}$, Kamp 1987) and the convergent component of which caused the uplift of the Southern Alps between about 8 to $5 \mathrm{Ma}$ (Tippett and Kamp 1993; Batt and Braun 2000). Nevertheless, the basin has been relatively stable since Late Cretaceous rifting, with tectonic activity limited to subsidence in the central part of the basin (Browne and Field 1988).

The stratigraphic record of the South Island of New Zealand is linked to the plate-tectonic evolution of the New Zealand Plateau with a firstorder $(80 \mathrm{My})$, tectonically controlled transgressive-regressive cycle developed in the Canterbury Basin (Carter and Norris 1976; Field and Browne 1989). Three stratigraphic groups, the Onekakara, Kekenodon, and Otakou groups (Carter and Carter 1982) were deposited during the regional transgressive, highstand, and regressive phases of the large-scale cycle, respectively (Fig. 2; Lu et al. 2003). The Onekakara Group sedimentary rocks consist mainly of alluvial sandstone, shallow marine siltstone, and mudstone. During the Oligocene highstand, reduced terrigenous influx resulted in the deposition of the basin-wide, pelagic to hemipelagic, bioclastic limestone of the Amuri Formation (Carter 1988). The upper boundary of this formation is a current-induced unconformity, the Marshall Paraconformity (Carter and Landis 1972), dated at about 32-29 Ma (Fulthorpe et al. 1996). The unconformity is overlain by mid-late Oligocene cross-bedded glauconitic sand of the Concord Formation, which in turn is overlain by limestone of the Weka Pass Formation, both making up the Kekenodon Group (Carter 1988). The Miocene to Recent regression was caused by increased sediment supply linked to Alpine Fault activity, resulting in a series of prograding clinoforms of the Otakou Group (Lu et al. 2003).

This paper presents results of study of core samples from limestone of the upper part of the Amuri Formation, which underlies the Marshall Paraconformity. This sedimentary interval was recovered in the basal $\sim 70 \mathrm{~m}$ cores of IODP Hole 317-U1352C (between 1924 to 1852 meters below sea floor, mbsf). The main focus is the stylolitization process in this white, coccolithophorid-foraminiferal biomicrite (Lewis 1992).

\section{METHODS}

We recorded stylolites and stylolitic seams from the bottom cores of IODP Hole 317-U1352C (bottom of core 148R; $1924 \mathrm{mbsf}$ ) up to the Marshall Paraconformity (core section 140R-2; 1852 mbsf). We classified each stylolite based on its morphology (cf. Park and Schot 1968), and recorded the depth (in mbsf) of occurrence, stylolite orientation, amplitude, thickness, and orientation of stylolite peaks. Spacing between stylolites reported in this paper is always measured on a continuous piece of the core (and thus uninterrupted by core breaks). Spacing between stylolites on separate pieces is not reported, because the missing section of core cannot be estimated. As a result, the number of stylolites recorded in each lithologic unit is larger than the number of measurements of stylolite spacing.

Transmitted polarization microscopy and cathodoluminescence microscopy on 12 thin-sections (preferentially sampled from areas in the core where stylolites or stylolitic seams occur) utilized a Zeiss Axioskop 40 microscope for transmitted light and a CITL Cathodoluminescence Mk5-2 stage mounted on a Nikon Eclipse 50i microscope with an attached Nikon DS-Filc digital camera for cathodoluminescence (CL). Operating conditions for the CL stage were about $270 \mu \mathrm{A}$ and $14 \mathrm{kV}$. We coated small stubs of samples containing stylolite to host-rock contacts with Au-Pd and studied them under a LEO 1455 VP scanning electron microscope (SEM) at the Natural History Museum (London). The SEM operated at EHT of $20 \mathrm{kV}$. We captured quantitative estimates of sedimentologic (lithology and grain composition of the host rock) and diagenetic features (stylolites, fractures, and cements) by point counting thin-sections (300 to 400 counts and step size of $0.3 \mathrm{~mm}$ ). Image analysis used thin-section scans (using a Canon CS9000F scanner) and the software Image J64, after using Photoshop to extract the color channels in which the features of interest (i.e., cements) are most apparent.

Aliquots of about 0.3 gram of 12 host-rock samples, acquired using a dental drill, were used for X-ray diffraction. We sampled host rock avoiding stylolites or stylolitic seams. We carried out X-ray analyses at the Natural History Museum (London) on a Philips PW 1830 diffractometer system using CuKá radiation and fitted with a PW 1820 goniometer and a graphite monochromator. We ran two series of analyses on the samples, one on the bulk rock and another on the separated clay fraction by dissolving carbonate and analyzing the residual in four ways, i.e., air-dried clay mounted on a ceramic tile, clay with addition of ethylene glycol (to show any expanding clays), clay heated to $400^{\circ} \mathrm{C}$ for two hours (for collapse of mixed layers to the illite position) and clay heated to $550^{\circ} \mathrm{C}$ for two hours (for the loss of crystallinity of the kaolinite and chlorite peaks). Operating conditions for the first series were $45 \mathrm{kV}$ and $40 \mathrm{~mA}$, scanning range between $2.5^{\circ}$ and $70^{\circ} 2 \theta$, step of $0.02^{\circ} 2 \theta$, and acquisition time of 2 seconds per step, while for the second series a scanning range between 2.5 and $40^{\circ}$ (for air dried clay) or $2.5^{\circ}$ and $26^{\circ} 2 \theta$ (for heated and glycolized clay), step of $0.015^{\circ} 2 \theta$, and acquisition time of 


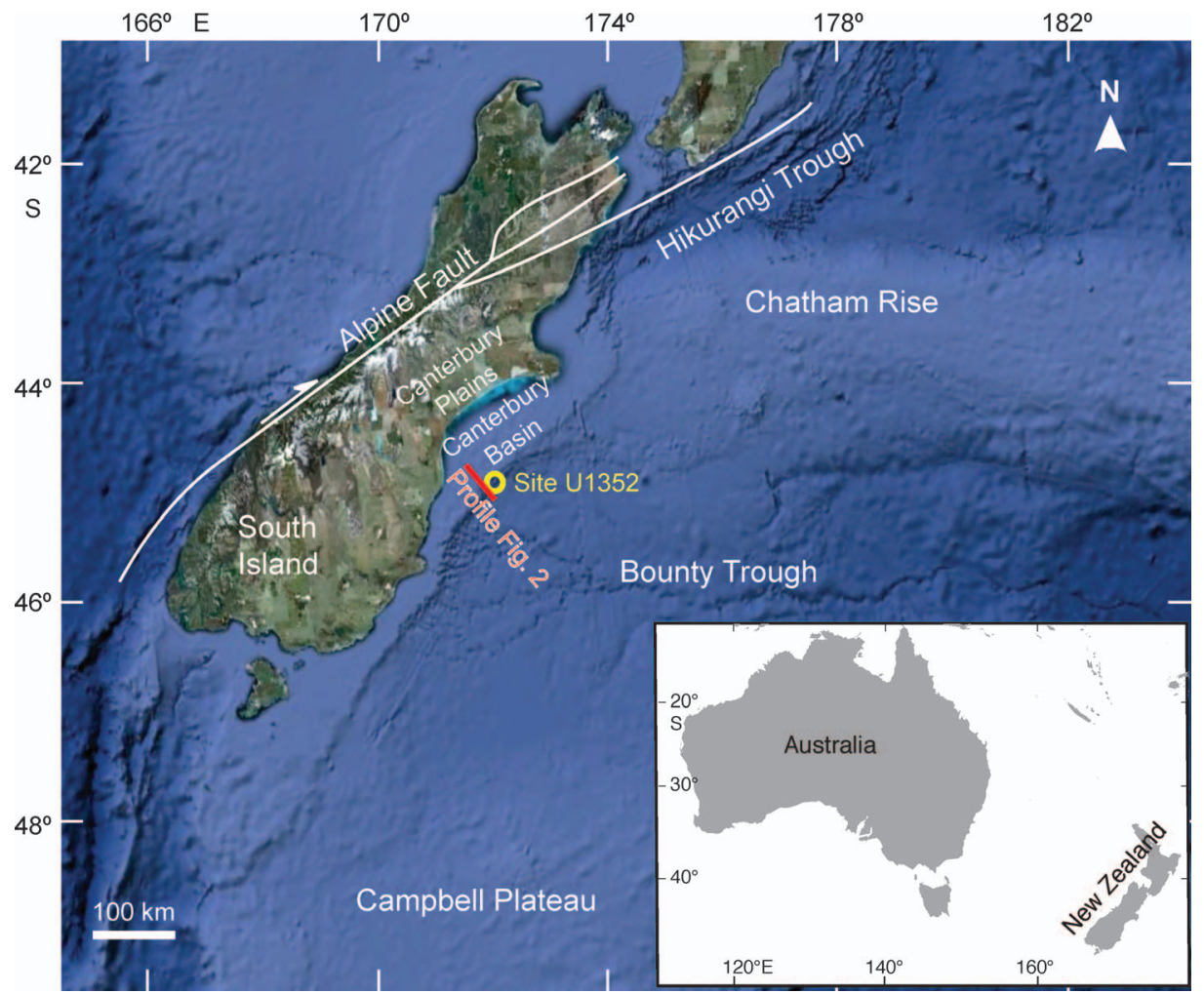

FIG. 1.- Map of the Canterbury Basin on the eastern margin of the South Island, New Zealand (modified from Fulthorpe et al. 2011). Location of site U1352 drilled during IODP Expedition 317 is indicated.
1 second per step. Quantitative estimates of the minerals present in the bulk analysis are based on the equations derived from Cuff (1969) for mixtures of calcite with other minerals (quartz in this study), whereas the quantification of clay is based on John et al. (2006).

We measured geochemical compositions on 12 thin-sections using a Cameca SX-100 electron microprobe at the Université de Montpellier II (France). We used two different methods, one optimized for carbonate and one for silicates. The carbonate method used a beam size of $15 \mu \mathrm{m}$, with detection limits of about $130 \mathrm{ppm}$ for $\mathrm{Na}, 80 \mathrm{ppm}$ for $\mathrm{Mg}, 50 \mathrm{ppm}$ for $\mathrm{S}, 120 \mathrm{ppm}$ for $\mathrm{Ca}, 150 \mathrm{ppm}$ for $\mathrm{Sr}, 75 \mathrm{ppm}$ for $\mathrm{Fe}, 90 \mathrm{ppm}$ for $\mathrm{Al}$, $50 \mathrm{ppm}$ for $\mathrm{Cl}$, and $50 \mathrm{ppm}$ for $\mathrm{K}$. The silicate method used a beam size of $9 \mu \mathrm{m}$, and included detection limits of about $3500 \mathrm{ppm}$ for F, $300 \mathrm{ppm}$ for $\mathrm{Na}, 200 \mathrm{ppm}$ for $\mathrm{Mg}, 150 \mathrm{ppm}$ for S, $200 \mathrm{ppm}$ for $\mathrm{Ca}, 600 \mathrm{ppm}$ for $\mathrm{Sr}$, $140 \mathrm{ppm}$ for $\mathrm{Fe}, 300 \mathrm{ppm}$ for $\mathrm{Si}, 220 \mathrm{ppm}$ for $\mathrm{Al}, 110 \mathrm{ppm}$ for $\mathrm{Cl}$, and

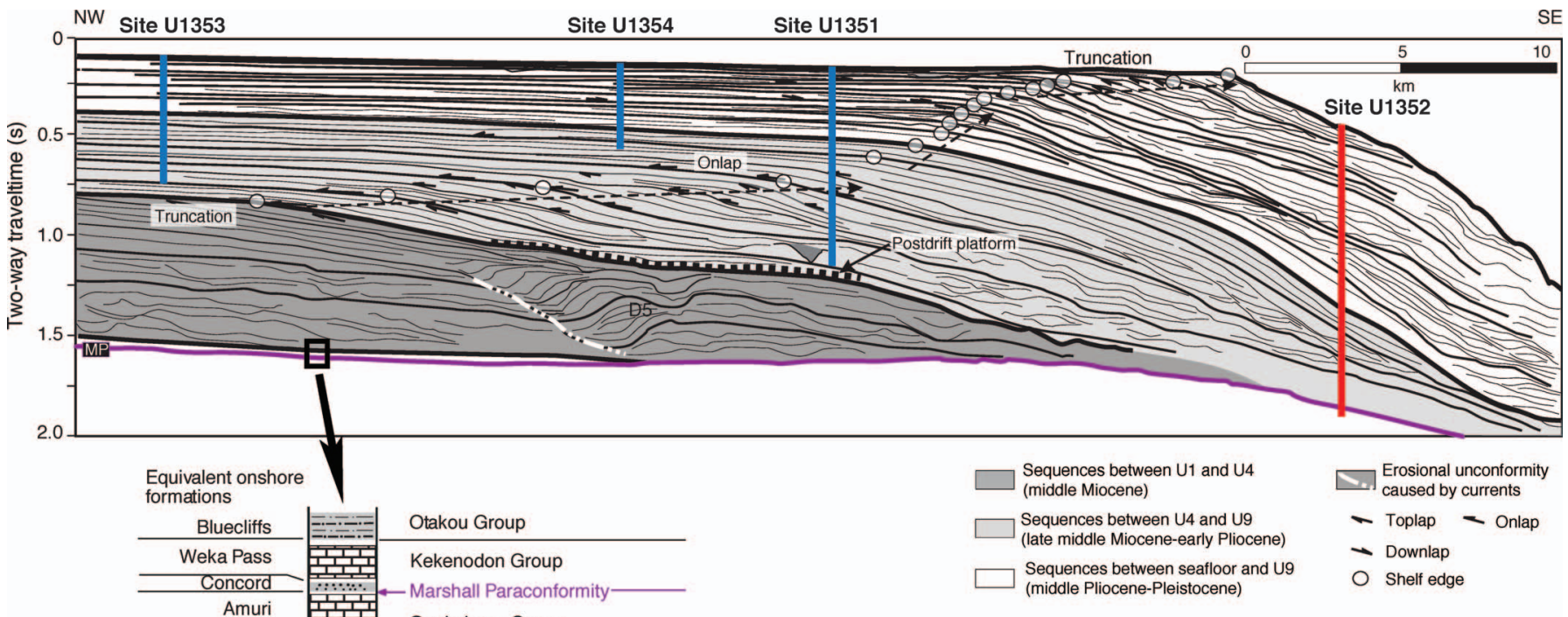

FIG. 2.- Interpreted seismic section showing locations of sites U1351, U1353, and U1354 and projected location of site U1352, all drilled by IODP Expedition 317. Seismic sequence boundaries (thicker lines) are shown, along with selected locations of onlap, truncation, and downlap (modified from Fulthorpe et al. 2011). Inset presents the outcrop-scale stratigraphy across the Marshall Paraconformity (modified from Fulthorpe et al. 1996) and thus zooming in on the Amuri Limestone (underlying the paraconformity), which is the focus of this study. 


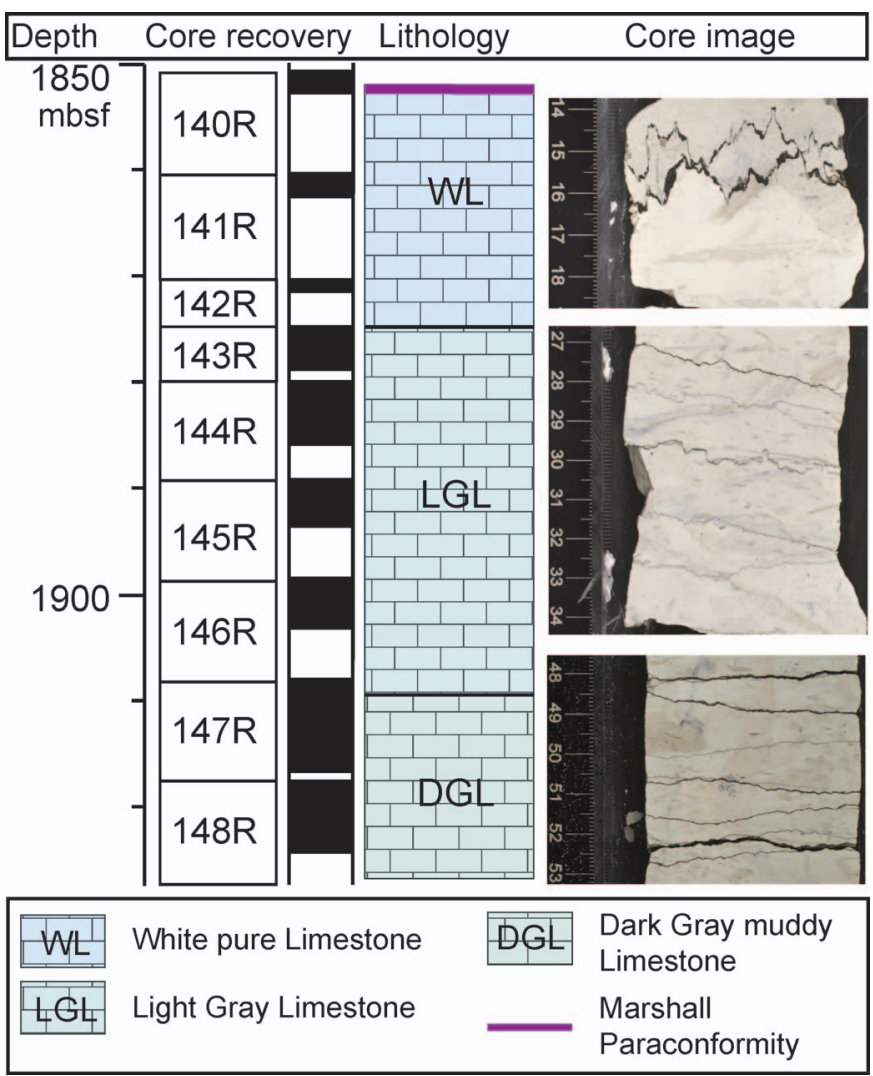

FIG. 3.- Log of study interval of the late Eocene to early Oligocene Amuri limestone with indication of core numbers and recovery. Cores from 141R-2, $145 \mathrm{R}-1$, and $148 \mathrm{R}-4$, respectively. Scale on core images is depth in respective core segment in centimeters. Recovered core is indicated in black. The core images show the change in color related to higher clay content from white limestone (WL) to light gray limestone (LGL) and dark gray limestone (DGL) lithologic units, as well as the larger-amplitude stylolites in WL compared to those in LGL and DGL.

$120 \mathrm{ppm}$ for K. Microprobe analysis corrections were based on Merlet (1994).

We carried out stable carbon and oxygen isotope analyses on carbonate powders (sampled with a dental drill) in the Qatar Stable Isotope Lab at Imperial College London following the method described in Vandeginste and John (2012). Precision is better than $0.01 \% 0(1 \sigma)$ for $\delta^{13} \mathrm{C}$ and $0.04 \%$ $(1 \sigma)$ for $\delta^{18} \mathrm{O}$ during the course of this study.

\section{RESULTS}

\section{Lithology and Diagenetic Features}

The cores consist of a dark gray muddy limestone (DGL) in the basal cores in the borehole (1924-1911 mbsf) that grades into a light gray limestone (LGL; 1911-1875 mbsf) and finally into a pure white limestone (WL) in the interval 1875-1852 mbsf, immediately below the Marshall Paraconformity (Fig. 3). X-ray diffraction reveals that all host-rock samples are dominated by calcite with only a low percentage of quartz. Traces of clays consist mainly of smectite (up to $89 \%$ of the total clay content; Table 1). The relative abundance of calcite and quartz varies among samples, with the highest calcite amount in the WL; the highest amount of smectite versus illite is in the DGL (Table 1).

The DGL is a planktic foraminiferal (50 to $200 \mu \mathrm{m}$ in diameter) wackestone that contains several seams or thicker (several-millimeter scale) zones that commonly are bedding-parallel and in thin-section appear darker than the matrix (Fig. 4A). Under CL, the bedding-parallel
TABLE 1.-XRD data from 12 core samples spread over the study interval.

Note that the data indicate a decrease in quartz/calcite ratio (and thus increase in calcite content) from DGL to $L G L$ and $W L$. The illitelsmectite ratio roughly increases from $D G L$ to $L G L$ and $W L$.

\begin{tabular}{lcccc}
\hline \hline $\begin{array}{l}\text { Core, Depth } \\
\text { in Core }\end{array}$ & Depth (mbsf) & Quartz/Calcite & Illite/Smectite & Lithologic Unit \\
\hline $141 \mathrm{R}-1,52 \mathrm{~cm}$ & 1861.32 & 0.04 & 0.10 & WL \\
$141 \mathrm{R}-1,111 \mathrm{~cm}$ & 1861.91 & 0.05 & 0.17 & WL \\
$142 \mathrm{R}-1,74 \mathrm{~cm}$ & 1871.15 & 0.05 & 0.11 & WL \\
$143 \mathrm{R}-1,31 \mathrm{~cm}$ & 1875.32 & 0.05 & 0.13 & LGL \\
$143 \mathrm{R}-1,74 \mathrm{~cm}$ & 1875.75 & 0.05 & 0.11 & LGL \\
$143 \mathrm{R}-1,134 \mathrm{~cm}$ & 1876.34 & 0.05 & 0.09 & LGL \\
$144 \mathrm{R}-1,27 \mathrm{~cm}$ & 1880.27 & 0.05 & 0.11 & LGL \\
$145 \mathrm{R}-1,42 \mathrm{~cm}$ & 1889.92 & 0.04 & 0.11 & LGL \\
$146 \mathrm{R}-1,118 \mathrm{~cm}$ & 1899.88 & 0.06 & 0.10 & LGL \\
$147 \mathrm{R}-1,66 \mathrm{~cm}$ & 1908.96 & 0.07 & 0.08 & LGL \\
$148 \mathrm{R}-1,147 \mathrm{~cm}$ & 1919.38 & 0.09 & 0.08 & DGL \\
$148 \mathrm{R}-5,9 \mathrm{~cm}$ & 1923.53 & 0.07 & 0.09 & DGL \\
\hline
\end{tabular}

seams generally have a slightly lighter brownish color than the matrix (Fig. 4B). The color of the micrite under the polarizing microscope varies from black to dark brownish, with a heterogeneous color pattern in thinsection. The LGL and WL also consist of planktic foraminifer wackestone (Fig. 4C) with a dull brownish luminescence under CL (Fig. 4D). Planktic foraminifera in the LGL (200 to $300 \mu \mathrm{m}$ in diameter) are slightly larger than those in the WL (100 to $150 \mu \mathrm{m}$ in diameter). Many foraminifer chambers are filled with micrite, and rarely are cemented by calcite. Rare benthic foraminifers (300 to $400 \mu \mathrm{m}$ in diameter) occur in the WL. Coccoliths between the micrite grains can be identified on SEM images (Fig. 5A). Point counting shows no marked difference in the abundance of foraminifers (generally about 15 to $20 \%$ ) among the DGL, the LGL, and the WL (Table 2). Samples that contain more than one stylolite have a greater abundance of clay along stylolite planes. Calcite cementation in the foraminifer chambers is greater in the LGL than in the DGL and the WL. The latter observation is also true for the quantitative analysis of thin-section scan images $(4500 \times 4500$ pixels, 6400 pixels/inch; Table 3).

Stylolites in the LGL and the WL generally are filled with brownish clay (Fig. 4C), and in some instances they are lined with pyrite. No characteristic features of clay types (such as kaolinite booklets or filamentous or fibrous illite) were evident using the SEM, because clay along the stylolites occurs as smooth surfaces (Fig. 5A), but XRD identified the clay as mainly smectite. There are no variations in the host-rock characteristics, such as porosity, as a function of the distance from the stylolite, but a thin opening commonly is present between the stylolite surface and the host rock (Fig. 5B). Most stylolites are parallel to bedding, with peaks perpendicular to bedding. A few veins perpendicular to bedding are connected to the stylolite, and are filled with inclusion-free calcite cement. The veins have a width of generally less than $50 \mu \mathrm{m}$ (but reach $250 \mu \mathrm{m}$ in one sample) and are overall short (less than $2 \mathrm{~mm}$ in length).

\section{Stylolite Morphology and Spacing}

The distribution of stylolites with different amplitudes is dependent on depth and host-rock lithology (Table 4): the stylolite amplitude (peak to trough) increase from the DGL (mean of $1.5 \mathrm{~mm}$ ) to the LGL (mean of $3 \mathrm{~mm}$ ) to the WL (mean of $10 \mathrm{~mm}$; Fig. 6A, B, D). Spacing between successive stylolites in the LGL (Fig. 6C) reveals an exponential distribution (with the distribution parameter $\lambda=0.08$, confirmed by chi-squared test at $95 \%$ confidence level). We also simulated random occurrence of stylolites by generating the same number of stylolites (807) in the total sum of the stylolite spacings $(9658 \mathrm{~mm})$. This was done by 

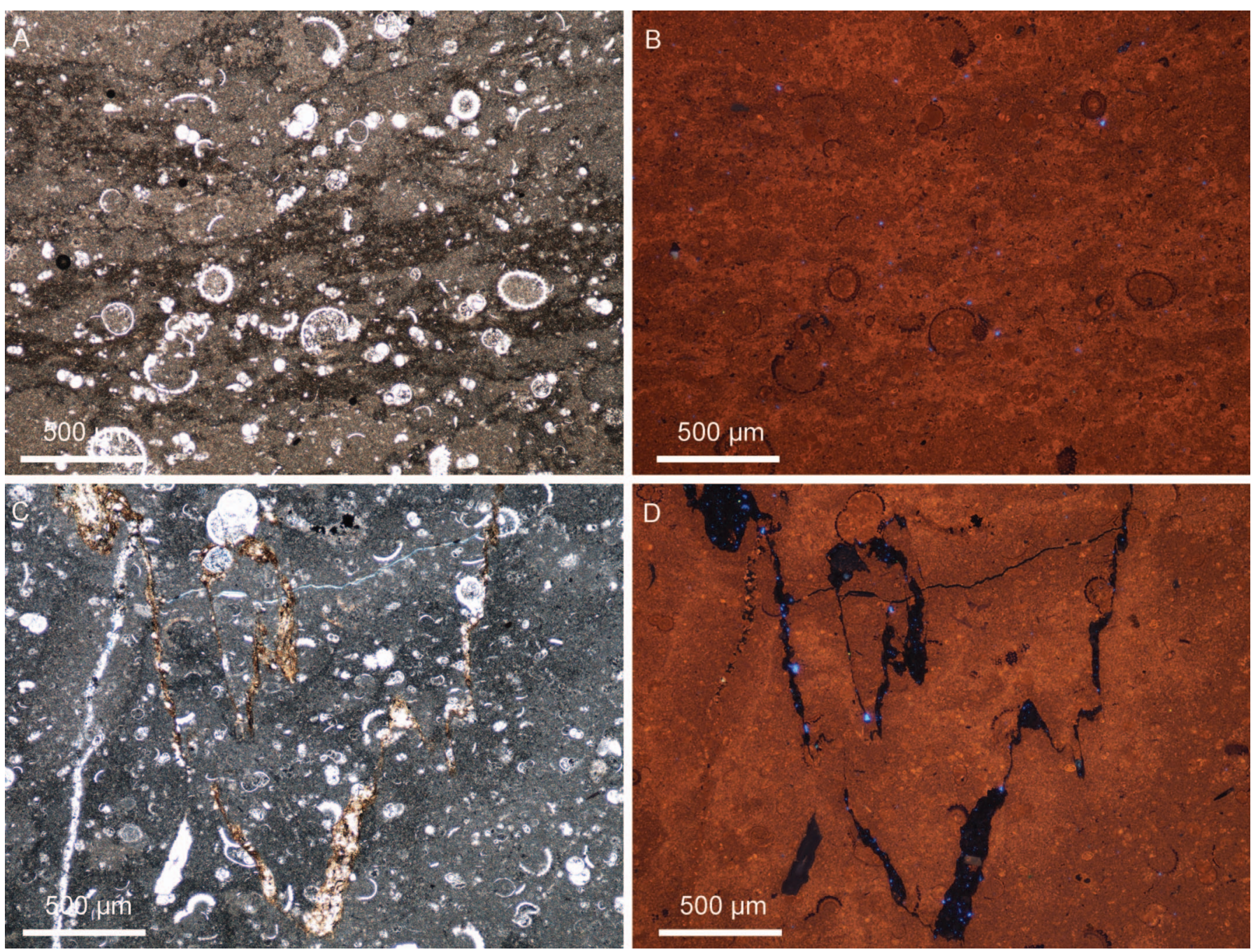

FIG. 4.-Transmitted-polarized-light and cathodoluminescence microphotograph of A, B) DGL sample with darker stylolitic seams and C, D) WL sample with stylolite. Both samples are planktic foraminiferal wackestones, but they have a different color (brownish for DGL samples and dark gray for WL sample) due to the higher clay content in DGL. The CL images show the dark luminescence of foraminifer shells compared to the orange-red luminescence of the mud. Also the stylolite is clearly visible (nonluminescent) in the WL sample.

taking 807 randomly generated numbers between 0 and 9658 by using the randbetween function in Microsoft Excel, then sorting these numbers and calculating the spacing. A chi-squared test (at the 98\% confidence level) comparing the stylolite spacing in LGL with the stylolite spacing by random stylolite generation shows that both curves have the same exponential distribution. An exponential distribution also fits the stylolite spacing in the DGL (Fig. 6E) better than a normal, lognormal, or Poisson distribution, but a chi-test at $95 \%$ confidence level rejects the null hypothesis of an exponential distribution fit. Since only one of the small core fragments (Table 4; Fig. 7) in the WL contains two stylolites allowing the measurement of spacing, no statistics can be calculated on the stylolite spacing in this lithology. Stylolite thickness is generally less than $1 \mathrm{~mm}$ and rarely exceeds 1 or $2 \mathrm{~mm}$. The $2 \mathrm{~mm}$ thick stylolites occur predominantly in the WL. The stylolite density in recovered core is much larger in the DGL and LGL than in the WL (Table 4).

Most stylolites are horizontal with bedding-perpendicular peaks (Fig. 3). Nonetheless, some stylolites are slightly oblique whilst retaining beddingperpendicular peaks; rarely, stylolites are strongly oblique and have peaks perpendicular to the stylolite planes (Fig. 8A). Oblique stylolites with peaks perpendicular to bedding crosscut bedding-parallel stylolites
(Fig. 8B) and most oblique stylolites with peaks perpendicular to the stylolite plane terminate on bedding-parallel stylolites or crosscut beddingparallel stylolites. In some cases, the orientation of the stylolite follows the rim of sedimentary features in the host rock, such as burrows (Fig. 8C).

Almost all stylolite morphology types described in Park and Schot (1968) occur throughout the succession and in each lithology (Fig. 9). However, the relative abundance of each stylolite type differs between lithologies. In general, the relative abundance of seismogram and wavetype stylolites decreases uphole, i.e., from the DGL to the WL, in contrast to the sharp-peak, sutured, and rectangular up-peak type stylolites, which increase in abundance uphole (Fig. 9). The rectangular down-peak stylolite type seems to occur dominantly in the LGL.

\section{Geochemical Signature of Micrite and Diagenetic Components}

Microprobe analyses on thin-sections reveal that the chemical composition of the micrite changes with depth. For example, $\mathrm{Mg}, \mathrm{Fe}$, $\mathrm{Al}$, and $\mathrm{K}$ concentrations generally decrease from the DGL to the WL, whereas the $\mathrm{Sr}$ and $\mathrm{Ca}$ content increases (Fig. 10). In general, the micrite has a lower $\mathrm{Ca}$ concentration than that measured in the calcite cement in 

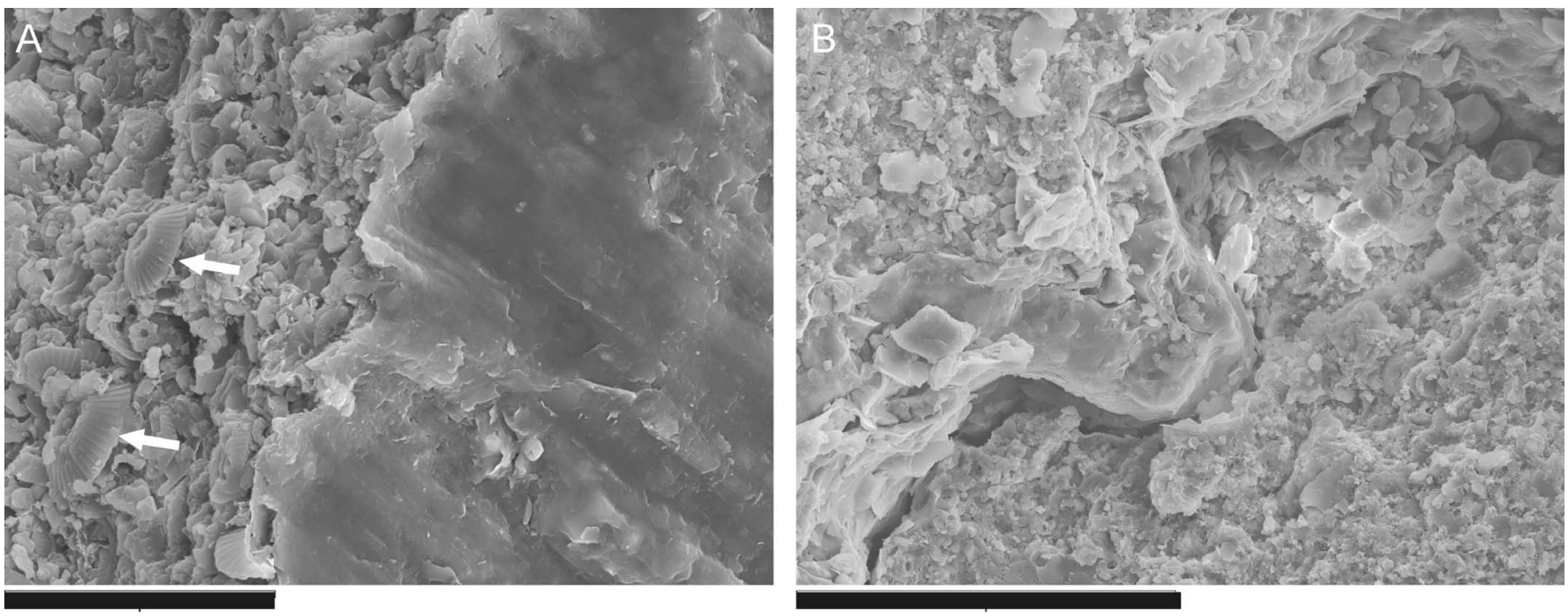

FIG. 5.-SEM images of host rock-stylolite contacts. A) Host rock (left) containing coccoliths (arrow) adjacent to stylolite with clay (right). Scale bar is $20 \mu \mathrm{m}$. B) Stylolite crosscutting host rock. Scale bar is $70 \mu \mathrm{m}$. No variation in porosity is obvious in the host rock.

both foraminifer chambers and in veins connected to stylolites (Fig. 11). The Fe concentration in the micrite overlaps with that measured in the calcite cement in the foraminifers and the veins (generally up to about $600 \mathrm{ppm}$ ), but some of the measurements in the micrite are much higher (mainly up to about $2100 \mathrm{ppm}$ ). Concentrations of $\mathrm{Na}, \mathrm{Al}$, and $\mathrm{K}$ are commonly below the detection limit (about 130, 90, and $50 \mathrm{ppm}$, respectively) in the calcite cement in foraminifer chambers and veins, in contrast to the higher (detectable) values in the micrite. Concentrations of $\mathrm{Ca}, \mathrm{Fe}, \mathrm{Mg}$, and $\mathrm{Sr}$ detected in the calcite cement do not show a pronounced variation with depth.

The clay along the stylolites has an average of about $23 \mathrm{wt} \% \mathrm{Si}, 7 \mathrm{wt} \%$ $\mathrm{Al}, 6 \mathrm{wt} \% \mathrm{Ca}, 2 \mathrm{wt} \% \mathrm{~K}, 1.4 \mathrm{wt} \% \mathrm{Fe}, 1.3 \mathrm{wt} \% \mathrm{Mg}$, and $0.2 \mathrm{wt} \% \mathrm{Na}$ (based on 16 analyses). $\mathrm{Sr}$ is below the detection limit (about $400 \mathrm{ppm}$ ) in the clay. No trend in clay-mineral elemental composition with depth is evident.

\section{Geochemical Variation along Cross-Stylolite Transects}

In addition to the general geochemical analyses reported above, targeted analyses along two short high-resolution transects and several longer lower-resolution transects through stylolites and adjacent limestone reveal an abrupt increase in $\mathrm{Mg}, \mathrm{Fe}, \mathrm{K}$, and especially $\mathrm{Al}$ and $\mathrm{Si}$ is evident in the stylolites, and a strong decrease in Ca compared to the surrounding limestone (Fig. 12). The variation in elemental concentration in longer, lower resolution transects in thin-section from the limestone adjacent to stylolites lack clear trends (Fig. 13).

Stable isotopes in small samples along three vertical transects across stylolites at different depths in the core reveal that variation in the stableisotope signature in each transect is small, i.e., about $0.3 \%$ for $\delta^{18} \mathrm{O}$ and $0.1 \%$ for $\delta^{13} \mathrm{C}$, and there are no consistent trends in the transects (Fig. 14).

\section{DISCUSSION}

\section{Control on Stylolite Amplitude and Density}

Stylolite amplitude is generally larger in grainstone and packstone than in mudstone and wackestone (e.g., Andrews and Railsback 1997; Railsback 1993), and generally larger in limestone than in dolostone, as documented in Paleozoic carbonates from the mid-Eastern United States (Railsback 1993) and in the Khuff Formation carbonate from offshore Abu Dhabi (Peacock and Azzam 2006). Still, the homogeneous wackestone texture throughout the DGL, LGL, and WL cannot explain the variation in stylolite morphology observed in this study (Fig. 6A, B, D).

TABLE 2.-Composition of the strata, based on point counting of thin-sections. Clay refers to clay concentrated along stylolites. Sparite represents calcite cement in foraminifer chambers or veins. Intraparticle pores (of $>5 \mu \mathrm{m}$ ) are captured, but the total intraparticle porosity is not presented in the table because it is less than $1 \%$ in the thin-sections.

\begin{tabular}{|c|c|c|c|c|c|c|c|c|}
\hline $\begin{array}{l}\text { Core, Depth } \\
\text { in Core }\end{array}$ & Depth (mbsf) & Forams $(\%)$ & Micrite $(\%)$ & Sparite $(\%)$ & Clay $(\%)$ & $\begin{array}{l}\text { Quartz and } \\
\text { Feldspar }(\%)\end{array}$ & Counts & Lithologic Unit \\
\hline $141 \mathrm{R}-1,52 \mathrm{~cm}$ & 1861.32 & 7.0 & 91.4 & 1.6 & 0.0 & 0.0 & 371 & WL \\
\hline $141 \mathrm{R}-1,111 \mathrm{~cm}$ & 1861.91 & 21.9 & 76.5 & 1.6 & 0.0 & 0.0 & 306 & WL \\
\hline 142R-1, $74 \mathrm{~cm}$ & 1871.15 & 25.3 & 71.9 & 2.6 & 0.0 & 0.3 & 388 & WL \\
\hline $143 \mathrm{R}-1,31 \mathrm{~cm}$ & 1875.32 & 17.1 & 78.1 & 3.8 & 0.0 & 1.0 & 315 & LGL \\
\hline $143 \mathrm{R}-1,74 \mathrm{~cm}$ & 1875.75 & 13.8 & 77.7 & 3.7 & 4.3 & 0.3 & 376 & LGL \\
\hline $143 \mathrm{R}-1,134 \mathrm{~cm}$ & 1876.34 & 19.8 & 73.3 & 4.7 & 2.3 & 0.0 & 348 & LGL \\
\hline 144R-1, $27 \mathrm{~cm}$ & 1880.27 & 23.5 & 68.5 & 5.9 & 2.1 & 0.0 & 340 & LGL \\
\hline $145 \mathrm{R}-1,42 \mathrm{~cm}$ & 1889.92 & 16.5 & 79.6 & 1.3 & 2.3 & 0.0 & 388 & LGL \\
\hline 146R-1, $118 \mathrm{~cm}$ & 1899.88 & 19.9 & 76.6 & 3.2 & 0.0 & 0.3 & 376 & LGL \\
\hline $147 \mathrm{R}-1,66 \mathrm{~cm}$ & 1908.96 & 15.7 & 81.3 & 1.9 & 0.8 & 0.3 & 364 & LGL \\
\hline $148 \mathrm{R}-1,147 \mathrm{~cm}$ & 1919.38 & 15.3 & 84.2 & 0.5 & 0.0 & 0.0 & 373 & DGL \\
\hline $148 \mathrm{R}-5,9 \mathrm{~cm}$ & 1923.53 & 16.4 & 81.9 & 1.7 & 0.0 & 0.0 & 348 & DGL \\
\hline
\end{tabular}


TABLE 3.-Overview of estimated limestone dissolution (based on stylolite amplitude, expressed as a percentage of pre-stylolitization limestone package) and calcite cement in veins and foraminifer chambers. The data are based on analysis of images $(4500 \times 4500$ pixels $)$ of three thin-sections for lithologic unit WL, seven for LGL, and two for DGL. Note that the estimated limestone dissolution is greater than the cement in veins and foraminifer chambers in each thin-section, suggesting net export.

\begin{tabular}{lccccc}
\hline \hline Unit & $\begin{array}{c}\text { Sum of Stylolite } \\
\text { Amplitudes }(\mathrm{m})\end{array}$ & $\begin{array}{c}\text { Total Recovered } \\
\text { Core }(\mathrm{m})\end{array}$ & $\begin{array}{c}\text { Estimated Limestone } \\
\text { Dissolution }(\%)\end{array}$ & $\begin{array}{c}\text { Cement in } \\
\text { Veins }(\%)\end{array}$ & $\begin{array}{c}\text { Cement in Foraminifer } \\
\text { Chambers }(\%)\end{array}$ \\
\hline WL & 0.24 & 2.91 & 7.6 & 0.1 & 0.2 \\
LGL & 2.95 & 20.80 & 12.4 & 0.5 & 1.4 \\
DGL & 0.93 & 11.59 & 7.4 & 0.0 & 1.1 \\
\hline
\end{tabular}

The offset in overburden pressure (linked to a difference in burial depth of up to $72 \mathrm{~m}$ between the bottom and top sample) is minimal and also unlikely to impact the stylolite amplitude: the deeper samples (in the LGL and the DGL) have smaller amplitudes than the shallower samples (in the WL), the reverse of what would be expected if overburden pressure alone was a control.

Although porosity in the original limestone can play a key role in stylolite initiation as more pore space induces larger stylolite amplitudes, as derived from stylolites in the southern Appalachian carbonates (Andrews and Railsback 1997), we found no evidence of original porosity differences between the DGL, LGL, and WL wackestones. Current porosity seems almost nil in thin-sections (Fig. 4), but the porosity measurements of generally 5 to $15 \%$ on core plugs (Table 5; Fulthorpe et al. 2011) suggest the presence of microporosity within the micrite. Microporosity in chalk is common and has a value of about $40 \%$ in mechanically compacted chalk at $1 \mathrm{~km}$ burial depth based on Cretaceous North Sea examples (Fabricius et al. 2008; Scholle 1977). No differences in initial microporosity between the DGL, LGL, and WL units are expected. The few larger porosity values in the WL (Table 5) may correspond to porosity along stylolites, or (less likely) along thin fractures, possibly an artifact of drilling and recovering the cores. These larger values probably reflect the result of later processes rather than larger initial porosity.

In this case, the main control on stylolite amplitude is possibly the abundance of clays. The role of sheet silicates in the pressure-solution process is not well understood. Clays can play an important catalytic role (Andrews and Railsback 1997) since they inhibit the precipitation of calcite, but do not retard its dissolution (Baker et al. 1980). Hence, stylolites tend to start at clay-calcite contacts, derived from observations in Cretaceous chalk from the North Sea and the Ontong Java Plateau (Fabricius and Borre 2007). Although the amount of clay could not be quantified (but the presence of mainly smectite and some illite was identified), the higher quartz content determined by XRD (Table 1), and the decrease in $\mathrm{Ca}$ and increase in $\mathrm{Al}, \mathrm{Fe}$, and $\mathrm{Mg}$ concentration detected by microprobe (Fig. 10) indicate higher siliciclastic content in the deeper, more muddy lithology (DGL). The higher siliciclastic content correlates with smaller stylolite amplitude (Fig. 15) by a power curve $\left(\mathrm{R}^{2}=0.59\right)$. In addition, seismogram and wave-type stylolites are more abundant than sharp-peak, rectangular, and sutured type stylolites in the muddy limestone (DGL; Fig. 9), consistent with a smoother stylolite morphology in carbonates with higher clay content (e.g., Barrett 1964).

Also, the density of stylolites can be impacted by lithology, with a higher abundance of stylolites in clay-rich limestone (Oldershaw and
Scoffin 1967), whereas no difference in stylolite density was reported between limestone and dolostone despite the difference in amplitude, as documented in Khuff carbonates from offshore Abu Dhabi (Peacock and Azzam 2006). These previous results are consistent with those in the Canterbury Basin, where larger stylolite density and smaller stylolite amplitude are observed in the clay-rich DGL and LGL compared to the more carbonate-rich WL (Fig. 15). Since stylolites can form barriers to fluid flow, the continuity of carbonate reservoirs is affected by the distribution of stylolites, which thus needs to be known for effective reservoir management, as documented for Middle Eastern Lower Cretaceous reservoirs (Koepnick 1985).

The stylolite spacing at Site U1352 is not consistent with the model of self-organization of stylolites (Merino 1992), which is based on a roughly regular spacing of stylolites. On the contrary, the distribution of stylolites derived from the large dataset ( $>800$ data) of spacing in the LGL is consistent with the interpretation of random arrangement of stylolites within intervals of similar lithology (Railsback 1998; Koehn et al. 2007). Our different approach, i.e., statistical analysis of a large dataset within a lithologic unit compared to the analysis of the coefficient of variation of spacing from several small datasets (Railsback 1998), reinforces the model of random arrangement of stylolites. The slight deviation for the stylolite spacing in the DGL is interpreted as a result of the occurrence of small lithological changes impacting on stylolite spacing in this large interval. Similarly, Lind (1993) suggested the impact of mineralogical anomalies and horizontal structures such as Zoophycos burrows on stylolite formation, based on observations in cores from the Ontong Java Plateau Cretaceous carbonates.

In the last decade, the stylolite structure was quantified by modeling stylolite shapes based on their fractal characteristics (Drummond and Sexton 1998). Modeling (of data sets of stylolites in Italy, southern France, and Germany) showed that stylolite roughness is not a function of (homogeneous or heterogeneous) grain size (Karcz and Scholz 2003; Ebner et al. 2010), and that heterogeneities, such as clay particles, play a crucial role in the formation of the distinctive roughness of stylolites because their resistance to dissolution differs (Brouste et al. 2007; Ebner et al. 2009a; Ebner et al. 2010; Renard et al. 2004; Schmittbuhl et al. 2004).

Although the exact nature of the heterogeneities (such as different minerals and pore spaces) plays only a minor role (Ebner et al. 2009a), their abundance impacts on stylolite amplitude (Ebner et al. 2009a). This concept is consistent with our observation of smaller stylolite amplitude with higher siliciclastic content. The amplitude of stylolites is limited, compatible with the suggestion of Koehn et al. (2007) that the growth of

TABLE 4.-Overview of core fragmentation and stylolite density, spacing, and amplitude in the three units.

\begin{tabular}{|c|c|c|c|c|c|c|c|}
\hline Unit & $\begin{array}{c}\text { Total } \\
\text { Interval (m) }\end{array}$ & $\begin{array}{l}\text { Total Recovered } \\
\text { Core }(\mathrm{m})\end{array}$ & $\begin{array}{c}\text { Average Core } \\
\text { Fragment Length }(\mathrm{cm})\end{array}$ & $\begin{array}{l}\text { Number of } \\
\text { Stylolites }\end{array}$ & $\begin{array}{c}\text { Stylolite Density } \\
\text { (per m recovered core) }\end{array}$ & $\begin{array}{l}\text { Average Stylolite } \\
\text { Spacing }(\mathrm{cm})\end{array}$ & $\begin{array}{l}\text { Average Stylolite } \\
\text { Amplitude }(\mathrm{cm})\end{array}$ \\
\hline WL & 22.38 & 2.91 & 3.4 & 25 & 8.6 & N/A & 0.95 \\
\hline LGL & 36.22 & 20.80 & 7.0 & 1063 & 51.1 & 1.2 & 0.28 \\
\hline
\end{tabular}



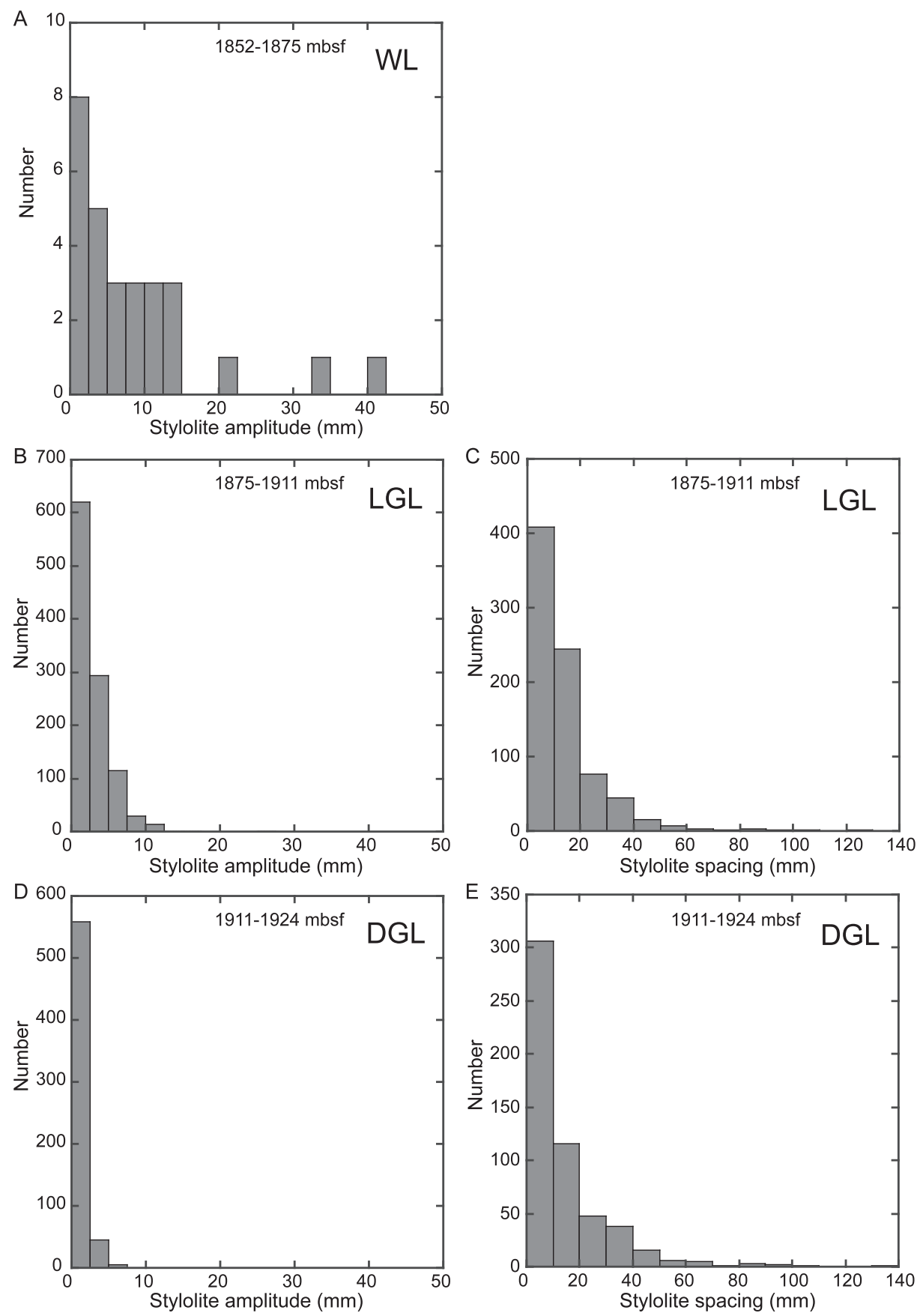

FIG. 6.-Histograms of A) stylolite amplitude (peak to trough) in the WL unit, B) stylolite amplitude in the LGL unit, C) stylolite spacing in the LGL unit, D) stylolite amplitude in the DGL unit, and $\mathbf{E}$ ) stylolite spacing in the DGL unit. The histograms show a decreasing distribution of large stylolite amplitudes from the WL unit (A) to the LGL unit (B) and then to the DGL unit (D). The stylolite spacing has an exponential distribution in the LGL unit (C). An exponential curve is also the best fit for stylolite spacing in the DGL unit (E).

the stylolite amplitude follows a power-law in time up to a critical threshold when the stylolite ceases to grow.

\section{Timing and Burial Depth during Stylolitization}

All bedding-parallel stylolites and oblique stylolites with beddingperpendicular peaks formed during burial as a result of overburden stress. This result is similar to the interpretation of the main shortening direction based on the direction of the stylolite peaks in the study on Matelles limestone in Languedoc, France (Petit and Mattauer 1995). The orientation of these oblique stylolites was controlled by the distribution of structures in the host rock, such as bioturbation (burrows) or thin fractures (similar to observations from Lind 1993 in the Ontong Java
Plateau). The influence of pre-existing microfractures or by competent components, such as pyrite crystals, on stylolite geometry was suggested by modeling results (Brouste et al. 2007).

The burial curve for the limestone of the Amuri Formation in the Canterbury Basin (Fig. 16) shows that the subsidence rates for the limestones were slow from the Oligocene to the mid-Miocene. Rates increased from the mid-Miocene onward, with the fastest rate occurring around the late Pliocene to early Pleistocene. A common depth for the initiation of stylolitization is 400 to $600 \mathrm{~m}$ (e.g., Nicolaides and Wallace 1997). Hence, bedding-parallel stylolitization probably started during mid to late Miocene, when such depths were reached for the limestone of the Amuri Formation at Site U1352. However, Nicol (1992) suggested the bedding-parallel stylolites in the onshore limestone of the Amuri 


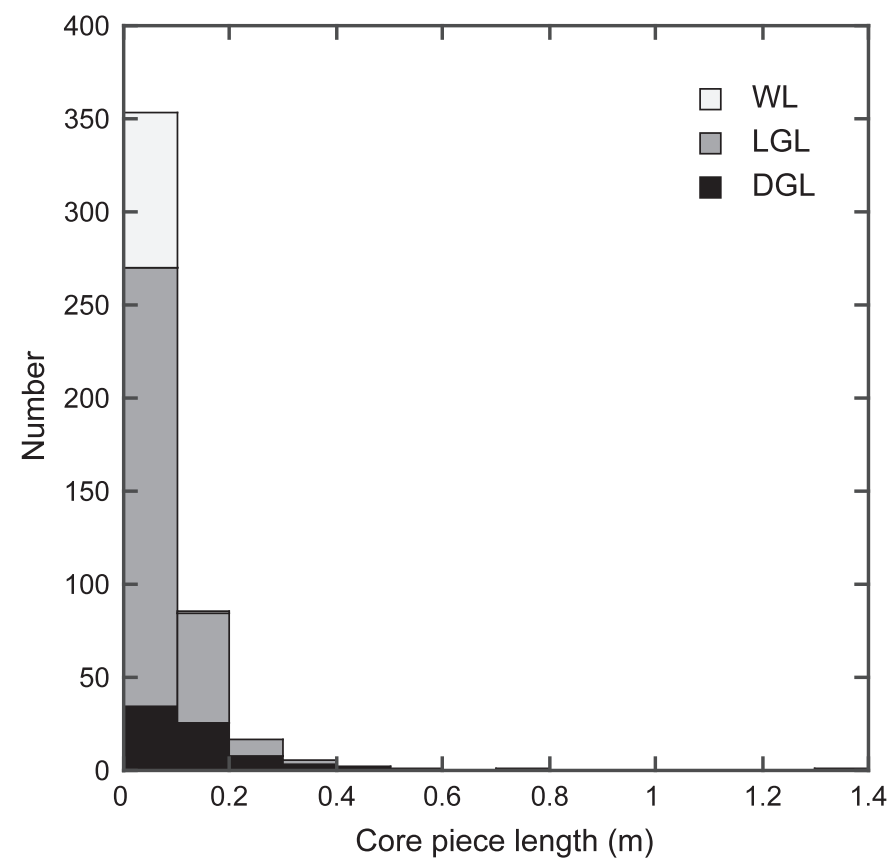

FIG. 7.- Histogram of length of core fragments in the various lithologic units. This histogram shows that all core fragments in the WL unit are $<10 \mathrm{~cm}$ long and the occurrence of two stylolites within one core fragment was rare in the WL unit. As a result, a representative analysis of spacing between stylolites was not possible for the WL unit. The LGL and DGL units are the most appropriate for a statistical evaluation of stylolite spacing because stylolite spacing is smaller and core pieces are larger.

Formation in North Canterbury (north of Christchurch) developed later, during Pliocene time. The discrepancy between the suggested ages can be explained by the different burial history, i.e., larger overburden package on the limestone from the Amuri Formation at Site U1352 than that onshore.

The occurrence of the oblique stylolite peaks indicates either the presence of a main principal stress that was not vertical, or that there has been rotation or folding of initially bedding-parallel stylolites. The observed crosscutting relationship, i.e., bedding-parallel stylolites (with perpendicular peaks) being crosscut by oblique stylolites (with perpendicular peaks) suggests that, in the first case, a nonvertical principal stress occurred later than the vertical principal stress, and in the second case, that no burial stylolites developed after rotation or folding. The orientation of the stylolites is important in reservoir characterization because the permeability is more reduced perpendicular to the stylolites than parallel with it (Nelson 1981). The limestone of the Amuri Formation contains bedding-normal stylolites onshore in North Canterbury (north of Christchurch), and these stylolites were attributed to Late Pliocene to early Pleistocene regional northwestsoutheast shortening (Nicol 1992). The age of the oblique stylolites at Site U1352 could be similar to those onshore, i.e., late Pliocene to early Pleistocene (Nicol 1992). But, the different orientation, i.e., perpendicular to bedding for the onshore limestone and oblique to bedding at Site U1352, may indicate that the oblique stylolites offshore were generated by a more local stress. The non-Andersonian stress state and the small number of oblique stylolites at Site U1352 compared to that onshore favors this hypothesis over a regional stress field. Moreover, the offshore Canterbury Basin has been an area of relative tectonic stability since Late Cretaceous rifting (Lu et al. 2003), thus arguing against significant tectonic stress that would lead to abundant stylolites normal or oblique to bedding. This observation implies that oblique stylolites could also be found in other tectonically passive areas due to local stress states rather than regional stress fields.

Reconstructing the timing of stylolite formation and understanding the diagenetic and burial history of the host rock is important to estimate the impact of stylolitization on reservoir properties. As Koepnick (1985) showed in Middle Eastern Lower Cretaceous carbonates, only stylolites that formed before oil emplacement are significant barriers to fluid flow via carbonate cementation associated with the stylolitization process because later oil coating inhibited further calcite cementation.

\section{Fluids Generated during Pressure Solution and Fluid Flow}

During stylolitization, grains in limestone dissolve at grain-to-grain contacts, and ions migrate by diffusion from zones of dissolution to zones of lower pressure, where they precipitate from the solution as intergranular cement (Drummond and Sexton 1998). Therefore, stylolitization can greatly impact on the porosity and permeability of the host rock. Previous studies report a higher-porosity zone in the range of a few micrometers from the stylolite (Carrio-Schaffhauser et al. 1990), but then a low-porosity zone farther from the stylolite, up to several centimeters in width, derived from sandstone examples in the North Sea and East Greenland (Harris 2006; Baron and Parnell 2007; Harris 2006).

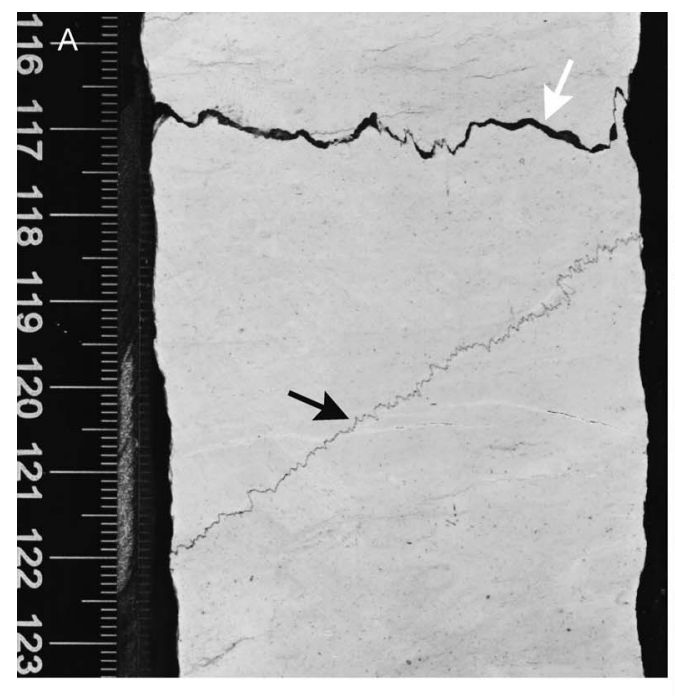

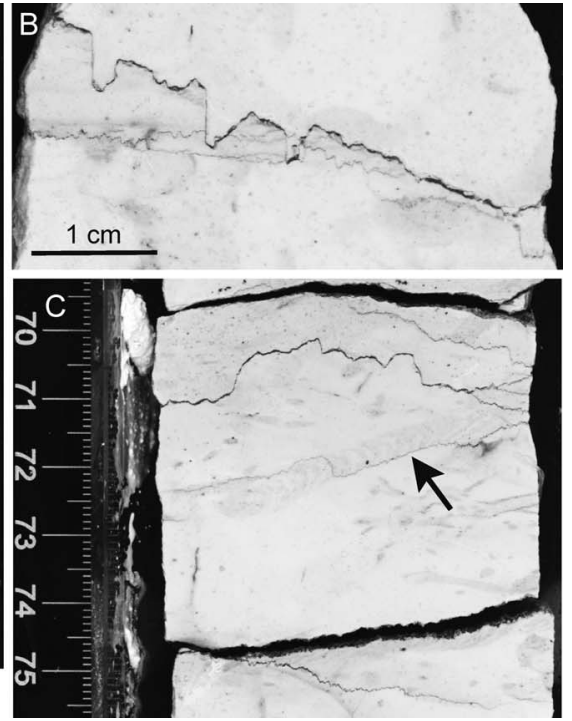

FIG. 8.-Core images showing bedding-parallel and oblique stylolites. Scale in centimeters. A) Bedding-parallel stylolite (white arrow) with thick $(1-1.5 \mathrm{~mm})$ clay seam and thin $(0.2 \mathrm{~mm})$ oblique stylolite (black arrow) with perpendicular peaks (core 145R-1). B) Bedding-parallel stylolites are crosscut by oblique stylolite with higher amplitude (core 147R-1). C) Beddingparallel stylolite and a smaller-amplitude stylolite that traces the rim of the burrow (black arrow; core 147R-1). 


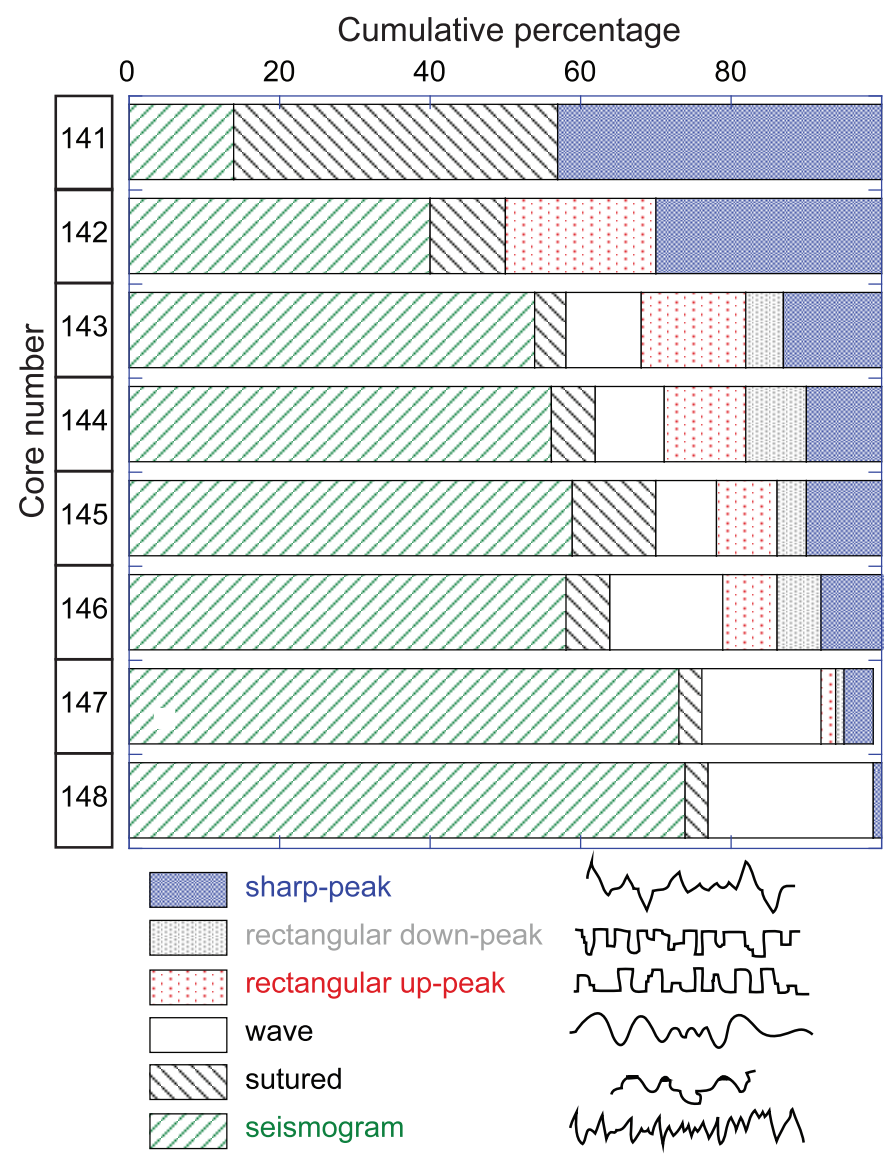

FIG. 9.- Histogram of cumulative percentages of stylolite type in the different cores. Each core is $9.6 \mathrm{~m}$ long, apart from core 142 and 143, which are half cores. Please refer to Figure 3 for depth of cores and boundaries between lithologic units (WL consist of cores 140-142, LGL consists of cores 143-top 147, and DGL of cores 147-148). The histogram shows that seismogram and wave stylolites increase in abundance from the WL to LGL and DGL units, whereas the sharp peak stylolites decrease in abundance from WL to LGL and DGL units.

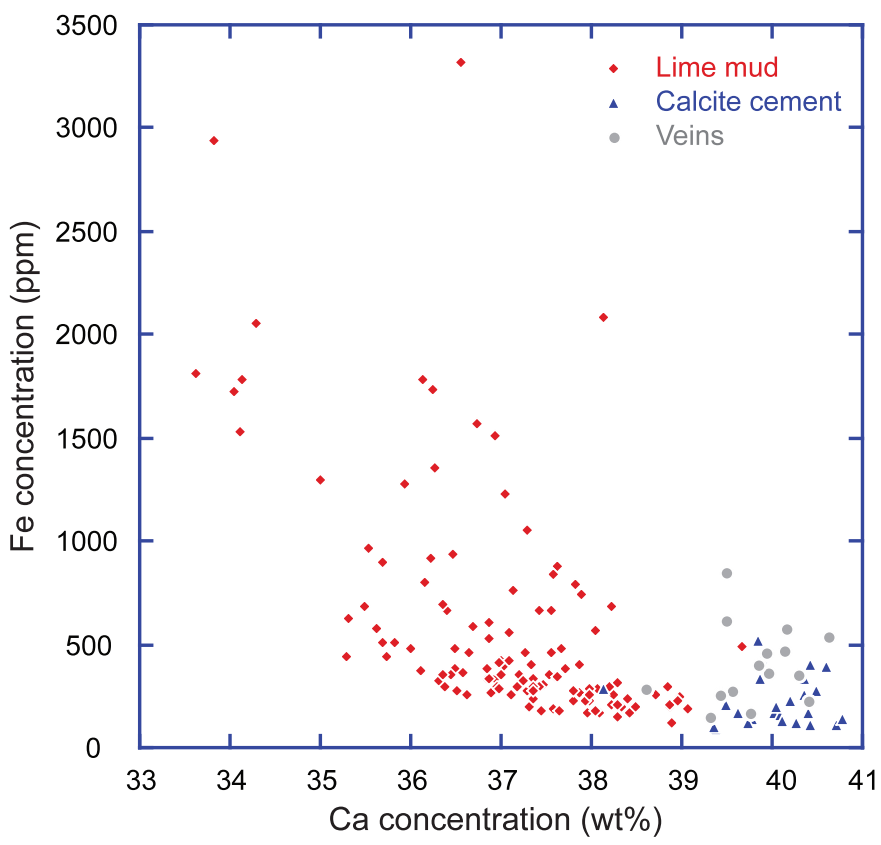

Fig. 11.-Concentration of Fe versus Ca measured in micrite, calcite cement filling foraminifer chambers (indicated as "calcite cement"), and calcite cement in veins connected to stylolites (indicated as "veins"). Six data points fall outside the value range of this plot. This plot shows that the calcite present in the veins and the cement is pure with an expected Ca content of about $40 \mathrm{wt} \%$. The lime mud is less pure with lower $\mathrm{Ca}$ concentration and a wider spread of higher Fe concentrations.

There is no evidence in the Canterbury Basin dataset for a variation in host-rock porosity close to the stylolites, which suggests that potential pressure-solution-related cements are homogeneously distributed within $1 \mathrm{~cm}$ distance from the stylolite. A thin porous zone is present at the contact between the stylolite and the host rock, but this contact may have been disturbed during drilling or sample preparation. Similarly, the stylolite-to-host-rock contact may have been affected by later diagenetic processes and, thus, may not reflect the stylolitization process itself.

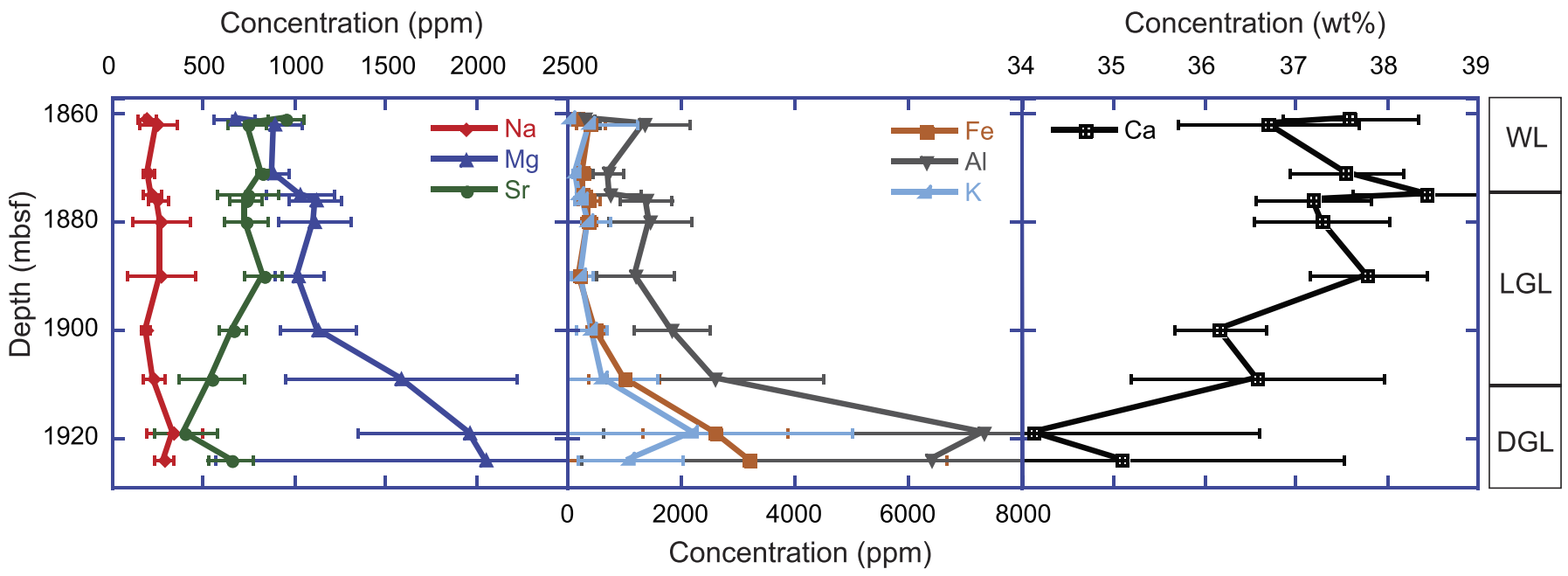

FIG. 10. - Chemistry of the micrite based on microprobe analyses. Concentrations are presented as average (with standard-deviation error bars) from thin-sections (presented as depth in the core). The concentrations of $\mathrm{Na}, \mathrm{Mg}, \mathrm{Sr}, \mathrm{Fe}, \mathrm{Al}$, and $\mathrm{K}$ are in ppm, whereas Ca is presented in weight percent. Note the different scale for the three boxes. The boundaries between the main lithologic units are indicated next to the plots. The plots show the higher concentration of $\mathrm{Mg}, \mathrm{Fe}, \mathrm{Al}$, and $\mathrm{K}$ and lower concentration of $\mathrm{Sr}$ and $\mathrm{Ca}$ in the DGL unit than in the LGL and WL units. 
A

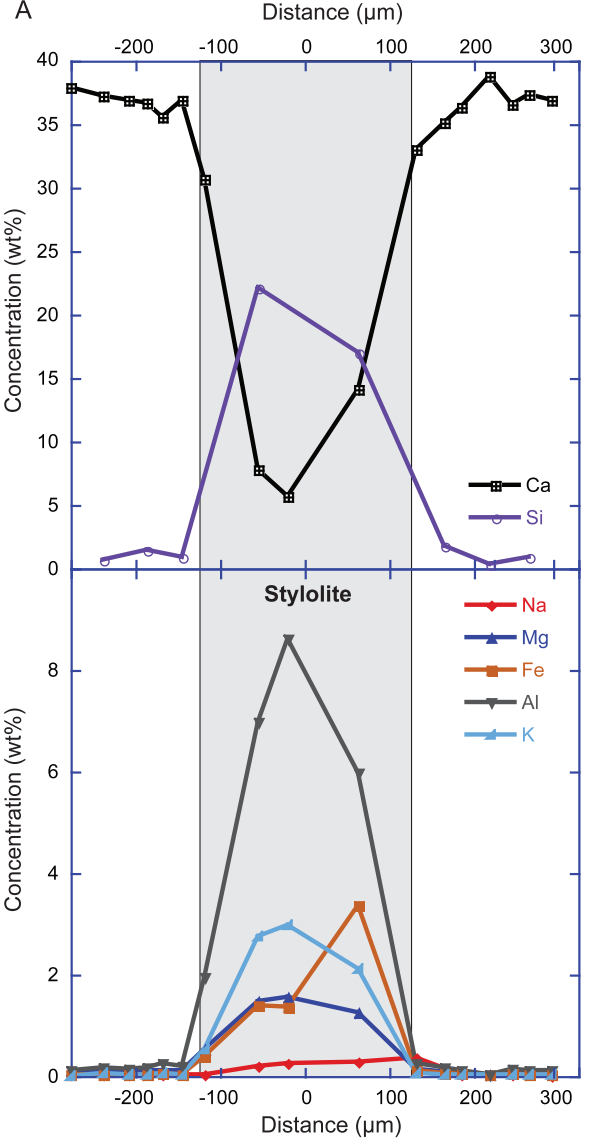

B

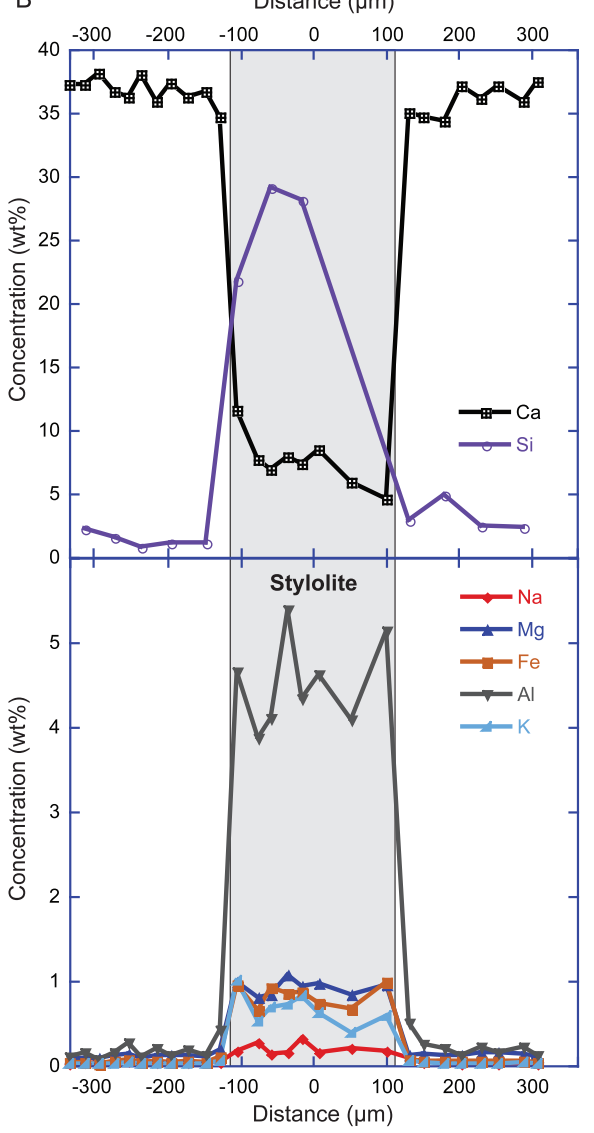

FIG. 12.-Variation in element concentrations along two high-resolution transects (spacing of about $30 \mu \mathrm{m}$ ) through two different stylolites and host rock. Both transects are along lines perpendicular to the bedding-parallel stylolites. The gray box indicates the actual stylolite, which has much higher concentrations of $\mathrm{Si}, \mathrm{Al}, \mathrm{Mg}$, $\mathrm{Fe}$, and $\mathrm{K}$ than the surrounding host rock. The relative abundance of $\mathrm{Si}>\mathrm{Al}>\mathrm{Mg}, \mathrm{Fe}$, and $\mathrm{K}$ is similar in the stylolites as in the limestone with higher clay content (DGL). Note the slight difference in minor-element concentrations between the two stylolites.
Thin veins perpendicular to, and connected with, stylolites contain calcite cement that most likely formed from precipitation by pressure-solution fluid. The amount of this calcite cement is, however, less than $0.2 \%$ of the total rock volume, whereas the estimated volume of limestone dissolved (based on stylolite amplitude; Bathurst 1975) is in the order of $7 \%$ to $12 \%$ (Table 3). Calcite cement present in the foraminifer chambers can also originate from stylolitization-generated fluid, but it amounts to less than $1.4 \%$ (Table 3). Even accounting for higher porosity of the limestone at time of stylolitization (e.g., maximum of $40 \%$ porosity) results in $4.7 \%$ of dissolved limestone, which is still greater than the amount of cement precipitated.

This excess of dissolved calcite compared to precipitated calcite suggests that part of the fluids generated during stylolitization were driven out of the sedimentary system. A similar scenario was presented for chalk from the Marchar Field in the North Sea, where about half of the dissolved calcite generated during pressure solution was reprecipitated as cement, and the other half left the sedimentary system (Safaricz and Davison 2005). Another hypothesis is that the pressure-solution fluids caused cement precipitation in the microporosity. This hypothesis is based on the porosity within the Amuri Limestone (5-15\%), which is lower than that expected (about 40\%) for Cretaceous chalk not having undergone pronounced cementation in the North Sea (cf. Fabricius 2003; Fabricius and Borre 2007). Similarly, a decrease of about $30 \%$ microporosity (from about $35 \%$ in the initial micritic sediment) is attributed to pressure-solution processes in clay-rich micritic shallow carbonate lithologies (petrophysical class D) in contrast to a decrease of about 15 or $20 \%$ in "micritic carbonates" of classes $\mathrm{C}$ and F respectively, linked to early diagenetic processes documented in Middle Eastern carbonates (Deville de Periere et al. 2011). Also, Moshier (1989) showed that zones of intense stylolitization are often linked to decreased microporosity in Lower Cretaceous micritic limestones in the Middle East. Microporosity seems preserved in chalk during burial diagenesis only under conditions of overpressure or displacement of pore water by hydrocarbons, as suggested by Maliva et al. (2009) based on a study of Eocene microporous limestone from south Florida.

Fluid flow during stylolitization is difficult to trace in geochemical data because the fluid composition will be very similar to the surrounding host rock being dissolved. Nevertheless, geochemical data provide some geological insight. The similar enrichment in elements (especially $\mathrm{Al}, \mathrm{Fe}$, $\mathrm{K}$, and $\mathrm{Mg}$ ) in the DGL micrite as in the clays along the stylolites (Figs. 10, 12) confirms that the clays are the insoluble residue resulting from stylolitization. This observation is consistent with results of Andrews and Railsback (1997) and Karcz and Scholz (2003), who argue against authigenesis of clays in stylolites. Still, the clay morphology (Fig. 5) suggests recrystallization (Andrews and Railsback 1997). During stylolitization, a type of "purification" process took place-clays originally present in the micrite are left behind on the stylolite plane, whereas the fluid (from dissolved limestone) forms "purified" calcite cement, which contains some $\mathrm{Mg}$ and $\mathrm{Sr}$, but very little $\mathrm{Fe}$ and practically no Al, K, and $\mathrm{Na}$ (i.e., below microprobe detection limit; Fig. 11).

The presence of stylolites can influence later diagenetic fluid flow or hydrocarbon migration. On the one hand, clays concentrated along the stylolite, as well as the generally low-porosity zone in the centimeter-scale wide host-rock zone adjacent to the stylolite, tend to act as a barrier to cross-stylolite flow. On the other hand, stylolites can become important conduits for stylolite-parallel flow, depending on diagenetic and tectonic conditions. For example, horizontal tectonic stresses can cause opening of bedding-parallel stylolites, and these stylolites can subsequently be 


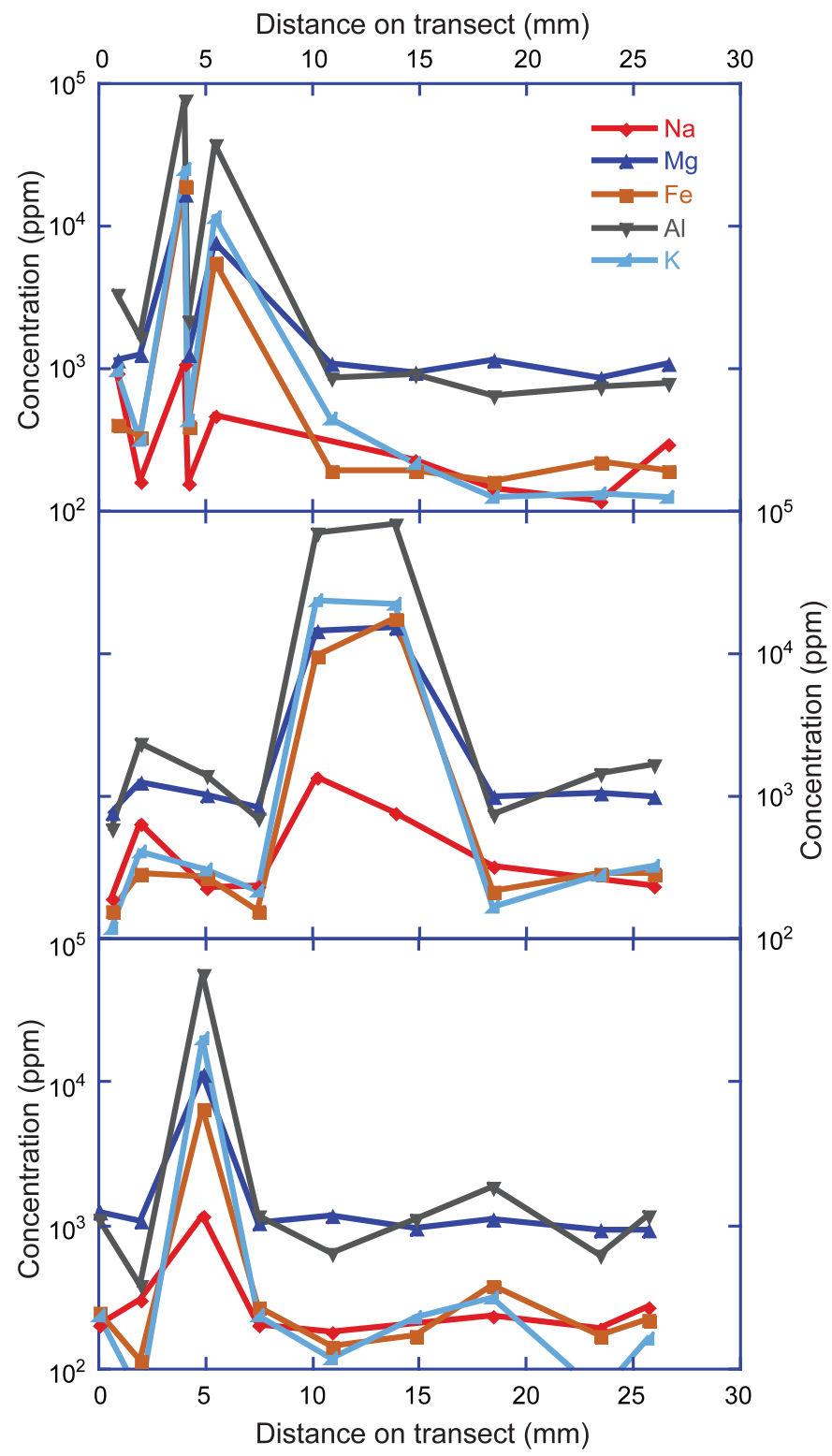

FIG. 13.-Variation in element concentrations along three low-resolution transects (perpendicular to the bedding) in the same thin-section of a sample containing stylolites (sample at depth of $1890 \mathrm{mbsf}$ ). Note the logarithmic scale for element concentration. The peaks correspond to stylolites. These transects show that the composition in the lime mud is homogeneous and that there are no element-concentration trends as a function of distance from the stylolites.

cemented by calcite or dolomite, as documented in Upper Jurassic limestone in eastern Spain (Marfil et al. 2005). In other cases, the stylolites are migration pathways for hydrocarbons, as documented for the Lower Triassic Virgin Member of the Moenkopi Formation in southern Nevada (Bissell 1972). Migration of fluids is also possible along active faults that represent reactivated pressure-solution structures, for example in the Matelles outcrop in the Languedoc region of France (Watkinson and Geraghty Ward 2006). In this study, neither the microprobe data nor the stable-isotope data along transects crosscutting the stylolites and host rock show evidence for alteration of the host-rock signature due to stylolite-controlled fluid flow (Figs. 13, 14). A similar result, i.e., lack of local enrichment or depletion in heavy isotopes of carbon or oxygen, was found by Lind (1993) on chalk from the Ontong

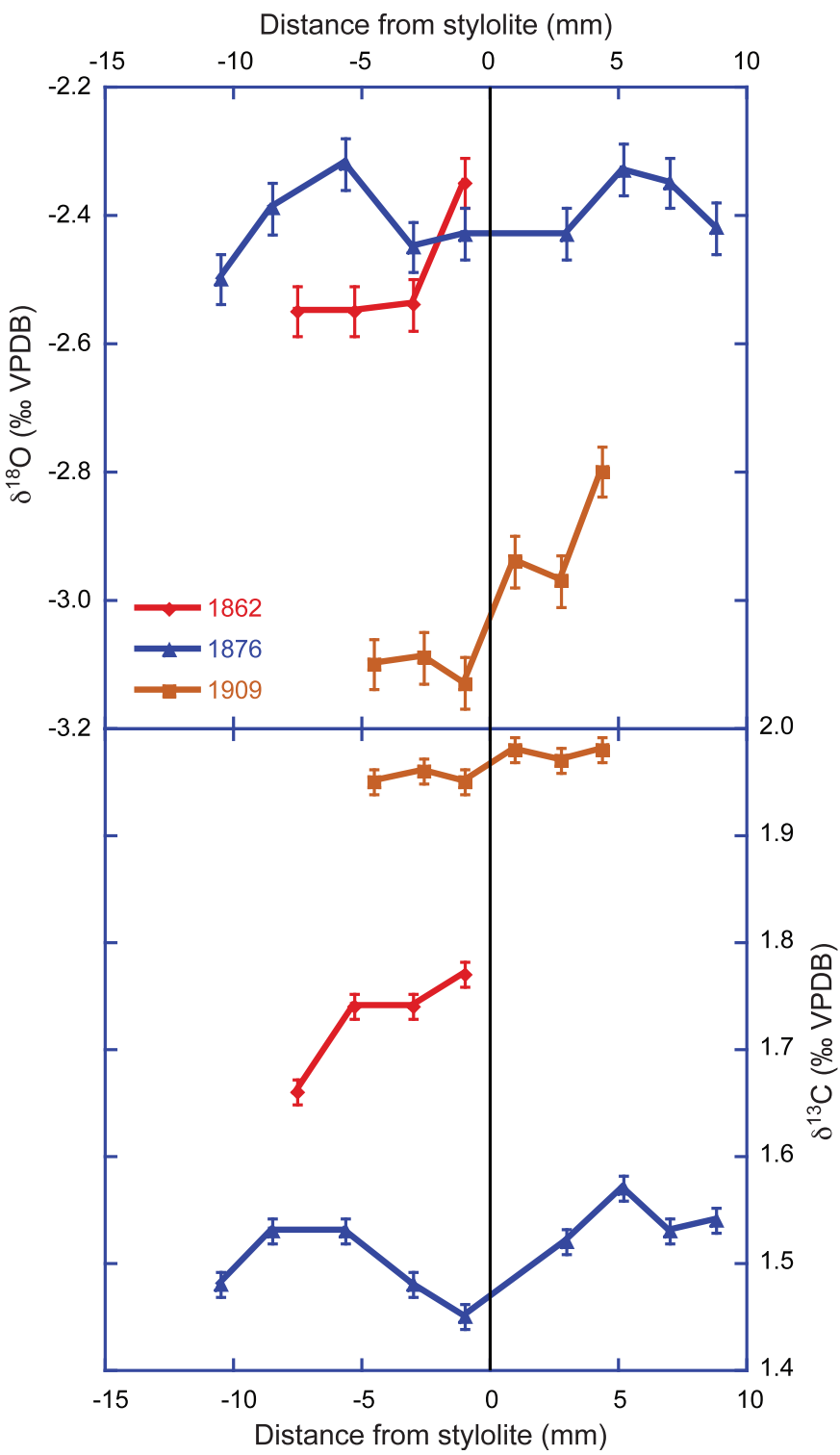

FIG. 14.- Variation in stable carbon and oxygen isotope composition along a transect perpendicular to a bedding-parallel stylolite. Distance is in millimeters from the stylolite, with positive values stratigraphically upwards and negative values representing distance below the stylolite. The transects are labeled by the depth of the sample in the core (in mbsf). The transects show no consistent trend in stable oxygen or carbon isotope compositions relative to the distance from the stylolite. This indicates that there was either no fluid flow along the stylolite or that this potential flow did not impact on the stable-isotope composition of the adjacent host rock.

Java Plateau. However, these results do not exclude the possibility of host-rock-buffered fluid flow along the stylolites.

\section{CONCLUSIONS}

This study gives three major insights into the stylolitization process. First, the siliciclastic content in the host rock is the main controlling factor on stylolite morphology and density in limestones with homogeneous texture. Higher siliciclastic content in the host rock causes a higher stylolite density (or lower stylolite spacing) but lower stylolite amplitude (following a power curve). This relation has implications for reservoir rocks: on the one hand, a higher stylolite 
TABLE 5.-Variation of porosity with depth in the core; data from Fulthorpe et al. (2011). Note that porosity estimated from the volume of pore water (calculated from loss of moisture after drying; Fulthorpe et al. 2011 ) is greater than that measured in thin-sections, suggesting the presence of microporosity (with pores $<1 \mu \mathrm{m}$ in diameter).

\begin{tabular}{|c|c|c|c|}
\hline Core, Depth in Core & Depth (mbsf) & Porosity (vol \%) & Lithologic Unit \\
\hline $140 \mathrm{R}-2,51 \mathrm{~cm}$ & 1852.67 & 10.6 & WL \\
\hline 141R-1, $94 \mathrm{~cm}$ & 1861.74 & 21.4 & WL \\
\hline $141 \mathrm{R}-2,32 \mathrm{~cm}$ & 1862.34 & 8.6 & WL \\
\hline $142 \mathrm{R}-1,67 \mathrm{~cm}$ & 1871.07 & 8.7 & WL \\
\hline $143 \mathrm{R}-1,82 \mathrm{~cm}$ & 1875.82 & 9.3 & LGL \\
\hline $143 \mathrm{R}-2,68 \mathrm{~cm}$ & 1877.18 & 9.5 & LGL \\
\hline $143 \mathrm{R}-3,78 \mathrm{~cm}$ & 1878.72 & 6.7 & LGL \\
\hline $144 \mathrm{R}-1,78 \mathrm{~cm}$ & 1880.78 & 9.2 & LGL \\
\hline $144 \mathrm{R}-2,51 \mathrm{~cm}$ & 1881.99 & 10.4 & LGL \\
\hline $144 \mathrm{R}-3,60 \mathrm{~cm}$ & 1883.55 & 7.8 & LGL \\
\hline $144 \mathrm{R}-4,5 \mathrm{~cm}$ & 1884.22 & 7.8 & LGL \\
\hline $145 \mathrm{R}-1,36 \mathrm{~cm}$ & 1889.86 & 7.9 & LGL \\
\hline $145 \mathrm{R}-1,123 \mathrm{~cm}$ & 1890.73 & 11.5 & LGL \\
\hline $145 \mathrm{R}-3,46 \mathrm{~cm}$ & 1892.91 & 12.4 & LGL \\
\hline $146 \mathrm{R}-1,98 \mathrm{~cm}$ & 1899.68 & 12.1 & LGL \\
\hline $146 \mathrm{R}-3,80 \mathrm{~cm}$ & 1902.50 & 10.5 & LGL \\
\hline $147 \mathrm{R}-1,60 \mathrm{~cm}$ & 1908.90 & 9.0 & LGL \\
\hline $147 \mathrm{R}-3,36 \mathrm{~cm}$ & 1911.57 & 10.8 & DGL \\
\hline $147 \mathrm{R}-5,96 \mathrm{~cm}$ & 1915.06 & 12.1 & DGL \\
\hline $147 \mathrm{R}-5,113 \mathrm{~cm}$ & 1915.23 & 15.0 & DGL \\
\hline $148 \mathrm{R}-1,42 \mathrm{~cm}$ & 1918.32 & 11.9 & DGL \\
\hline $148 \mathrm{R}-2,116 \mathrm{~cm}$ & 1920.56 & 11.8 & DGL \\
\hline $148 \mathrm{R}-3,8 \mathrm{~cm}$ & 1920.93 & 11.4 & DGL \\
\hline $148 \mathrm{R}-3,40 \mathrm{~cm}$ & 1921.25 & 19.2 & DGL \\
\hline $148 \mathrm{R}-5,59 \mathrm{~cm}$ & 1924.03 & 13.5 & DGL \\
\hline
\end{tabular}

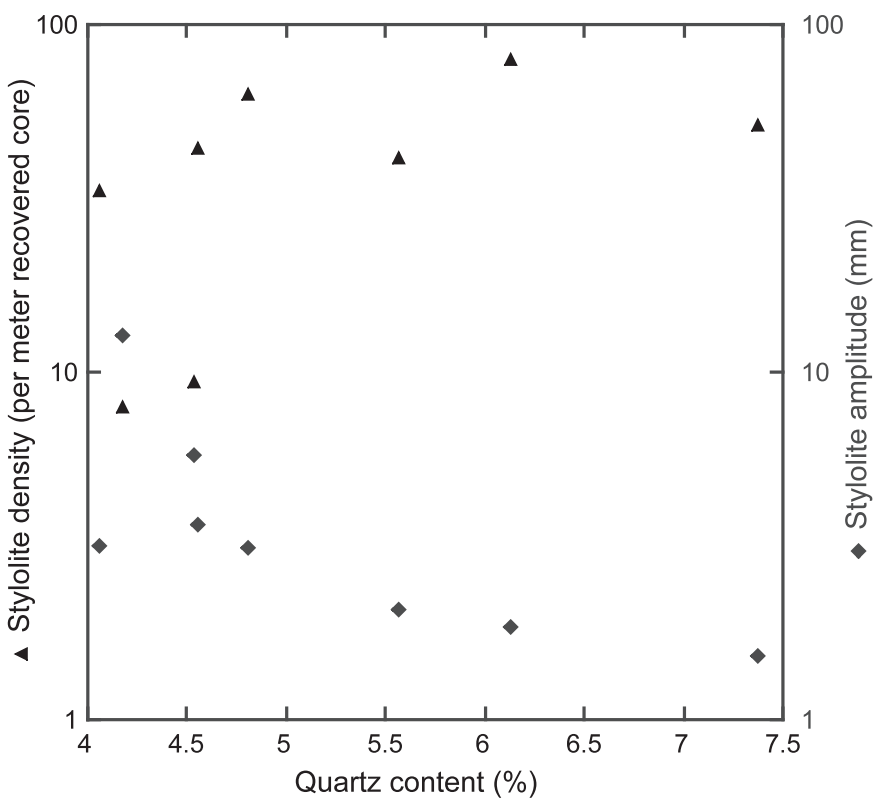

FIG. 15.-Plot of stylolite amplitude (in millimeter) and stylolite density (number of stylolites per meter of recovered core) versus quartz content (estimated from XRD) in the host rock. Note the increase of stylolite density and decrease of stylolite amplitude with increasing quartz content in host rock. The best-fit trendline is a power curve for stylolite amplitude $\left(\mathrm{Y}=213 \mathrm{X}^{-2.6} ; \mathrm{R}^{2}=0.59\right)$ and a logarithmic curve for stylolite density $\left(Y=72 \ln (X)-75 ; R^{2}=0.36\right)$ as a function of quartz content.

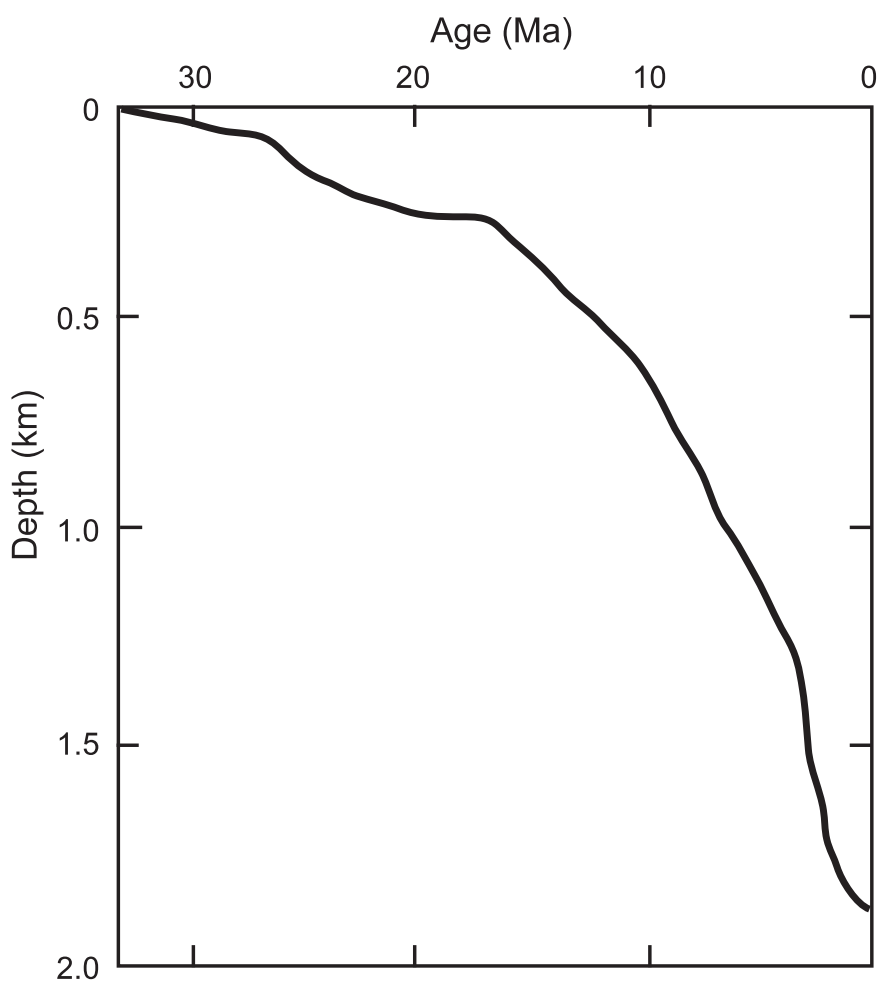

FIG. 16.-Burial curve (total subsidence) for the limestone of the Amuri Formation (at 1900 mbsf) in the Canterbury Basin (modified from Fulthorpe et al. 2011).

density implies a larger abundance of potential barriers or baffles to cross-stylolite flow; on the other hand, the smoother stylolite morphology may result in faster fluid flow along the stylolite plane when the latter is opened by tectonic stress or fluid overpressure in the reservoir. Second, the different statistical approach to evaluate stylolite spacing (than previous studies) does not support the stress-induced selforganization model (Merino 1992), but reinforces random arrangement of stylolites as previously suggested by Railsback (1998). The spacing of stylolites impacts on both fluid flow rates and patterns, and diagenetic heterogeneities in reservoirs, since higher stylolite densities create zones of lower permeability. Third, the minimum estimate of host-rock dissolution generated by stylolitization during less than $2 \mathrm{~km}$ burial compaction in pelagic limestones is 7 to $12 \mathrm{vol} \%$ of the original limestone. The amount of dissolved limestone is larger than the observed amount of cement, suggesting that the microporosity (most likely $40 \%$ when stylolitization started) was partly cemented by precipitation from fluids generated during pressure solution. These results highlight the importance of microporosity (which is difficult to quantify in thinsection) as a sink for cementation.

\section{ACKNOWLEDGMENTS}

This research used samples and data provided by the Integrated Ocean Drilling Program (IODP). We thank the Expedition 317 Scientific Party for their work on the Joides Resolution. Funding for this research was partially provided by the Arthur Holmes Centenary Research Grant awarded to the first author. We thank Martin Gill (XRD), Anton Kearsley (SEM), Simon Davis (stable isotopes), Claude Merlet and Bernard Boyer (microprobe) for their help with various analytical techniques. We also acknowledge John Cosgrove for commenting on the first draft of this manuscript. We are indebted to JSR editor Gene Rankey, associate editor Elias Samankassou, and the two reviewers Bruce Railsback and Ida Fabricius, whose comments were invaluable in improving the content and presentation of this manuscript. 


\section{REFERENCES}

Andrews, L.M., AND Railsback, L.B., 1997, Controls on stylolite development: morphologic, lithologic, and temporal evidence from bedding-parallel and transverse stylolites from the U.S. Appalachians: Journal of Geology, v. 105, p. 59-73.

Baker, P.A., Kastner, M., Byerlee, J.D., And Lockner, D.A., 1980, Pressure dissolution and hydrothermal recrystallization of carbonate sediments - an experimental study: Marine Geology, v. 38, p. 185-203.

Baron, M., And Parnell, J., 2007, Relationships between stylolites and cementation in sandstone reservoirs: examples from the North Sea, U.K. and East Greenland: Sedimentary Geology, v. 194, p. 17-35.

Barrett, P.J., 1964, Residual seams and cementation in Oligocene shell calcarenites, Te Kuiti group: Journal of Sedimentary Petrology, v. 34, p. 524-531.

Bathurst, R.G.C., 1975, Developments in Sedimentology: Carbonate Sediments and Their Diagenesis, Volume 12: Amsterdam, Elsevier Science, 658 p.

Bathurst, R.G.C., 1987, Diagenetically enhanced bedding in argillaceous platform limestones - stratified cementation and selective compaction: Sedimentology, v. 34, p. 749-778.

Batt, E., And Braun, J., 2000, Thermochronological analysis of the dynamics of the Southern Alps, New Zealand: Geological Society of America, Bulletin, v. 112, p. 250 266.

Bissell, H.J., 1972, Three-dimensional stylolites and migratory routes of oil and gas: American Association of Petroleum Geologists, Bulletin, v. 56, p. 604-604.

Braithwaite, C.J.R., 1989, Stylolites as open fluid conduits: Marine and Petroleum Geology, v. 6, p. 93-96.

Brouste, A., Renard, F., Gratier, J.P., and Schmittbuhl, J., 2007, Variety of stylolites' morphologies and statistical characterization of the amount of heterogeneities in the rock: Journal of Structural Geology, v. 29, p. 422-434.

Browne, G.H., AND Field, B.D., 1988, A review of Cretaceous-Cenozoic sedimentation and tectonics, east coast, South Island New Zealand, in James, D.P., and Leckie, D.A., eds., Sequences, Stratigraphy, Sedimentology: Surface and Subsurface: Canadian Society of Petroleum Geologists, Memoir 15, p. 65-87.

Buxton, T.M., And Sibley, D.F., 1981, Pressure solution features in a shallow buried limestone: Journal of Sedimentary Petrology, v. 51, p. 19-26.

Carrio-Schaffhauser, E., Raynaud, S., Latiere, H.J., and Mazerolle, F., 1990, Propagation and localization of stylolites in limestones, in Knipe, R.J., and Rutter, E.H., eds., Deformation Mechanics, Rheology and Tectonics: Geological Society of London, Special Publication 54, p. 193-199.

CARTER, R.M., 1988, Plate boundary tectonics, global sea-level changes and the development of the eastern South Island continental margin, New Zealand, Southwest Pacific: Marine and Petroleum Geology, v. 5, p. 90-107.

Carter, R.M., and Carter, L., 1982, The Motunau Fault and other structures at the southern edge of the Australian-Pacific plate boundary, offshore Marlborough, New Zealand: Tectonophysics, v. 8, p. 133-159.

Carter, R.M., and Landis, C.A., 1972, Correlative Oligocene unconformities in southern Australasia: Nature (London), Physical Science, v. 237, p. 12-13.

CArTer, R.M., AND Norris, R.J., 1976, Cainozoic history of southern New Zealand: an accord between geological observations and plate-tectonic predictions: Earth and Planetary Science Letters, v. 31, p. 85-94.

CufF, C., 1969, The crystallography and geochemistry of authigenic sulphate and carbonate minerals of the Recent sediments of the Trucial Coast [Unpublished Ph. D. thesis]: University of London, $311 \mathrm{p}$.

Deville de Periere, M., Durlet, C., Vennin, E., Lambert, L., Bourillot, R., Caline, B., AND POLI, E., 2011, Morphometry of micrite particles in cretaceous microporous limestones of the Middle East: influence on reservoir properties: Marine and Petroleum Geology, v. 28, p. 1727-1750.

Drummond, C.N., And Sexton, D.N., 1998, Fractal structure of stylolites: Journal of Sedimentary Research, v. 68, p. 8-10.

Dunnington, H.V., 1954, Stylolite development post-dates rock induration: Journal of Sedimentary Petrology, v. 24, p. 27-49.

Ebner, M., Koehn, D., Toussaint, R., and Renard, F., 2009a, The influence of rock heterogeneity on the scaling properties of simulated and natural stylolites: Journal of Structural Geology, v. 31, p. 72-82.

Ebner, M., Koehn, D., Toussaint, R., Renard, F., and Schmittbuhl, J., 2009b, Stress sensitivity of stylolite morphology: Earth and Planetary Science Letters, v. 277, p. 394-398.

Ebner, M., Piazolo, S., Renard, F., and Koehn, D., 2010, Stylolite interfaces and surrounding matrix material: nature and role of heterogeneities in roughness and microstructural development: Journal of Structural Geology, v. 32, p. 1070-1084.

FABRICIUS, I.L., 2003, How burial diagenesis of chalk sediments controls sonic velocity and porosity: American Association of Petroleum Geologists, Bulletin, v. 87, p. 1755-1778

Fabricius, I.L., AND Borre, M.K., 2007, Stylolites, porosity, depositional texture, and silicates in chalk facies sediments. Ontong Java Plateau-Gorm and Tyra fields, North Sea: Sedimentology, v. 54, p. 183-205.

Fabricius, I.L., Gommesen, L., Krogsbøll, A., and Olsen, D., 2008, Chalk porosity and sonic velocity versus burial depth: influence of fluid pressure, hydrocarbons, and mineralogy: American Association of Petroleum Geologists, Bulletin, v. 92, p. 201-223.

Field, B.D., And Browne, G.H., 1989, Cretaceous and Cenozoic Sedimentary Basins and Geological Evolution of Canterbury Region, South Island, New Zealand: New Zealand Geological Survey, Basin Studies 2.
Fletcher, R.C., And Pollard, D.D., 1981, Anti-crack model for pressure solution surfaces: Geology, v. 9, p. 419-424.

Fulthorpe, C.S., Carter, R.M., Miller, K.G., and Wilson, J, 1996, Marshall Paraconformity: a mid-Oligocene record of inception of the Antarctic Circumpolar current and coeval glacio-eustatic lowstand?: Marine and Petroleum Geology, v. 13, p. 61-77.

Fulthorpe, C.S., Hoyanagi, K., Blum, P., and the Expedition 317 Scientists, 2011, Proceedings IODP, 317: Tokyo, Integrated Ocean Drilling Program Management International, doi:10.2204/iodp.proc.31732011.

Harris, N.B., 2006, Low-porosity haloes at stylolites in the feldspathic Upper Jurassic Ula sandstone, Norwegian North Sea: an integrated petrographic and chemical massbalance approach: Journal of Sedimentary Research, v. 76, p. 444459.

John, C.M., Adatte, T., And Mutti, M., 2006, Regional trends in clay mineral fluxes to the Queensland margin and ties to middle Miocene global cooling: Palaeogeography, Palaeoclimatology, Palaeoecology, v. 233, p. 204-224.

Kamp, P.J.J., 1987, Age and origin of the New Zealand Orocline in relation to Alpine Fault movement: Geological Society of London, Journal, v. 144, p. 641-652.

Karcz, Z., And Scholz, C.H., 2003, The fractal geometry of some stylolites from the Calcare Massiccio Formation, Italy: Journal of Structural Geology, v. 25, p. 1301-1316

Koenn, D., Renard, F., Toussaint, R., and Passchier, C.W., 2007, Growth of stylolite teeth patterns depending on normal stress and finite compaction: Earth and Planetary Science Letters, v. 257, p. 582-595

KoEPNICK, R.B., 1985, Impact of stylolites on carbonate reservoir continuity: Example from Middle East: American Association of Petroleum Geologists, Bulletin, v. 69, p. $274-274$

LEWIS, D.W., 1992, Anatomy of an unconformity on mid-Oligocene Amuri Limestone, Canterbury, New Zealand: New Zealand Journal of Geology and Geophysics, v. 35, p. $463-475$.

LIND, I.L., 1993, Stylolites in chalk from Leg 130, Ontong Java Plateau in Berger, W.H., Kroenke, L.W., Janecek, T.R., and Sliter, W.V., eds., Otong Java Plateau: Proceedings of the Ocean Drilling Program, Scientific Results, v. 130, p. 445-451.

Lu, H., Fulthorpe, C.S., And Mann, P., 2003, Three-dimensional architecture of shelfbuilding sediment drifts in the offshore Canterbury Basin, New Zealand: Marine Geology, v. 193, p. 19-47.

Maliva, R.G., Missimer, T.M., Clayton, E.A., And Dickson, J.A.D., 2009, Diagenesis and porosity preservation in Eocene microporous limestones, South Florida, USA Sedimentary Geology, v. 217, p. 85-94.

Marfil, R., Caja, M.A., Tsige, M., Al-Aasm, I.S., Martín-Crespo, T., and Salas, R. 2005, Carbonate-cemented stylolites and fractures in the Upper Jurassic limestones of the Eastern Iberian Range, Spain: a record of palaeofluid composition and thermal history: Sedimentary Geology, v. 178, p. 237-257.

Merino, E., 1992, Self-organization in stylolites: American Scientist, v. 80, p. 466

Merlet, C., 1994, An accurate computer correction program for quantitative electron probe microanalysis: Mikrochimica Acta, v. 114-115, p. 363-376.

Moshier, S.O., 1989, Development of microporosity in a micritic limestone reservoir, Lower Cretaceous, Middle East: Sedimentary Geology, v. 63, p. 217-240

Nelson, R.A., 1981, Significance of fracture sets associated with stylolite zones: American Association of Petroleum Geologists, Bulletin, v. 65, p. 2417-2425.

NicoL, A., 1992, Tectonic structures developed in Oligocene limestones: implications for New Zealand plate boundary deformation in North Canterbury: New Zealand Journal of Geology and Geophysics, v. 35, p. 353-362.

Nicolaides, S., and Wallace, M.W., 1997, Pressure-dissolution and cementation in an Oligo-Miocene non-tropical limestone (Clifton Formation), Otway Basin, Australia in James, N.P., and Clarke, J.A.D., eds., Cool-Water Carbonates: SEPM, Special Publication 56, p. 249-261.

Oldershaw, A.E., AND Scoffin, T.P., 1967, The source of ferroan and non-ferroan calcite cements in the Halkin and Wenlock Limestones: Geological Journal, v. 5, p. 309-320

PARK, W.C., AND Schot, E.H., 1968, Stylolites: their nature and origin: Journal of Sedimentary Petrology, v. 38, p. 175-191.

Peacock, D.C.P., And Azzam, I.N., 2006, Development and scaling relationships of a stylolite population: Journal of Structural Geology, v. 28, p. 1883-1889.

Petit, J.P., And Mattauer, M., 1995, Palaeostress superimposition deduced from mesoscale structures in limestone: the Matelles exposure: Journal of Structural Geology, v. 17 , p. 245-256.

RaILSBACK, L.B., 1993, Lithologic controls on morphology of pressure-dissolution surfaces (stylolites and dissolution seams) in Paleozoic carbonate rocks from the Mideastern United States: Journal of Sedimentary Petrology, v. 63, p. 513-522.

RaILSBACK, L.B., 1998, Evaluation of spacing of stylolites and its implications for selforganization of pressure dissolution: Journal of Sedimentary Research, v. 68, p. 2-7. Raynaud, S., AND CARrio-SchaffHAuser, E., 1992, Rock matrix structures in a zone influenced by a stylolite: Journal of Structural Geology, v. 14, p. 973-980.

Renard, F., Schmittbuhl, J., Gratier, J.P., Meakin, P., and Merino, E., 2004, Threedimensional roughness of stylolites in limestones: Journal of Geophysical ResearchSolid Earth, v. 109, p. B03209, doi: 10.1029/2003JB002555

Safaricz, M., and Davison, I., 2005, Pressure solution in chalk: American Association of Petroleum Geologists, Bulletin, v. 89, p. 383-401.

Schmittbuhl, J., Renard, F., Gratier, J.P., and Toussaint, R., 2004, Roughness of stylolites: implications of $3 \mathrm{D}$ high resolution topography measurements: Physical Review Letters, v. 93, p. 238501.

Scholle, P.A., 1977, Chalk diagenesis and its relation to petroleum exploration: oil from chalks, a modern miracle?: American Association of Petroleum Geologists, Bulletin, v. 61, p. 982-1009. 
Sinha-Roy, S., 2002, Kinetics of differentiated stylolite formation: Current Science, v. 82 , p. $1038-1046$.

Stockdale, P.B., 1922, Stylolites: their nature and origin: Indiana University Studies, v. 9, p. 1-97.

Tada, R., AND Siever, R., 1989, Pressure solution during diagenesis: Annual Review of Earth and Planetary Sciences, v. 17, p. 89-118.

Tippett, J.M., AND KamP, P.J.J., 1993, Fission track analysis of the Late Cenozoic: vertical kinematics of continental Pacific Crust, South Island: New Zealand Journal of Geology and Geophysics, v. 36, p. 497-504
VAndeginste, V., AND John, C.M., 2012, Influence of climate and dolomite composition on dedolomitization: insights from a multi-proxy study in the central Oman Mountains: Journal of Sedimentary Research, v. 82, p. 177-195.

Watkinson, A.J., And Geraghty Ward, E.M., 2006, Reactivation of pressure-solution seams by a strike-slip fault-sequential, dilational jog formation and fluid flow: American Association of Petroleum Geologists, Bulletin, v. 90, p. 1187-1200.

Received 21 December 2011; accepted 3 December 2012. 